\title{
A magyar modell: A válságkezelés magyar receptje a mediterrán út tükrében*
}

\author{
Matolcsy György - Palotai Dániel
}

A tanulmány az eurozóna mediterrán országcsoportja és Magyarország által a válság kezelésére alkalmazott eszközöket vizsgálja. Az összehasonlítás alapját az adta, hogy a válság egy-egy időszakában az érintett országoknak hasonló kihivásokkal kellett szembenéznie és gyors gazdaságpolitikai beavatkozás vált szükségessé, ugyanis az addigi gyakorlat fenntarthatatlannak bizonyult. Az alkalmazott eszközök azonban különbözőek voltak, így az eredmények is. 2010 után Magyarország az egyensúlyt a foglalkoztatás és a növekedés javitásán keresztül kívánta elérni, amelynek fö eszközei az adóreform és a költségvetés strukturális reformja volt, majd ezt támogatták 2013-tól - a monetáris politikai fordulatot követöen - a Magyar Nemzeti Bank célzott intézkedései is. A gazdaságpolitika két fö ágának összehangolt müködéséből összességében egy innovativ, növekedésbarát gazdaságpolitika született, amely 2013-tól megteremtette a makropénzügyi egyensúly és a növekedés rég nem látott egységét. Ezzel szemben az eurót használó mediterrán országok alapvetően a hagyományos válságkezelési receptet alkalmazták: feláldozták a növekedést az egyensúly oltárán, de így utóbbit is számottevően később érték el, mint Magyarország. A válságból való kilábalást esetükben az euroövezeti tagságból adódó, kötött monetáris politika is korlátozta. A célzott magyar lépések jó példát nyújthatnak más, hasonló kihívásokkal szembesülő országok számára is.

Journal of Economic Literature (JEL) kódok: E52, E58, E62, H21, O23

Kulcsszavak: fiskális politika, monetáris politika, gazdaságpolitikai összhang, magyar gazdaságtörténet, Laffer-görbe, válságkezelés

\section{Bevezető}

A globális pénzügyi válság elsősorban azokat az országokat állitotta rendkivüli kihívás elé, amelyekben a gazdasági növekedés újraindítását a költségvetési és makropénzügyi stabilizáció mellett kellett elérni. A hagyományos válságkezelési esz-

\footnotetext{
* A jelen kiadványban megjelenő írások a szerzők nézeteit tartalmazzák, ami nem feltétlenül egyezik a Magyar Nemzeti Bank hivatalos álláspontjával.

Matolcsy György a Magyar Nemzeti Bank elnöke.

Palotai Dániel a Magyar Nemzeti Bank ügyvezetö igazgatója és föközgazdásza. E-mail: palotaid@mnb.hu

A szerzők köszönetet mondanak Baksay Gergelynek, Szalai Ákosnak, Hausmann Róbertnek, Berta Dávidnak és Meizer Gábornak a cikk készítése során nyújtott segítségükért.

A magyar nyelvű kézirat első változata 2018. április 4-én érkezett szerkesztőségünkbe.
}

DOI: http://doi.org/10.25201/HSZ.17.2.542 
közök e két cél közül csak az egyik elérésére alkalmasak, de akkor is a másik kárára. A magyar gazdaságpolitika 2010 utáni modellváltása az innovativ és célzott eszközök alkalmazásával azonban nemzetközi viszonylatban is egy eredményes válságkezelést eredményezett, rámutatva, hogy megfelelő megközelítésben feloldható a válságkezelés e dilemmája és párhuzamosan elérhető az egyensúly és a növekedés.

A válság kitörése után tíz évvel időszerü levonni a tanulságokat. A közgazdászok körében ma is folyik a gazdasági modellek átértelmezése és fejlesztése, az olyan korábban elhanyagolt területek hatásainak beillesztésével, mint a pénzügyi közvetítő rendszer, az egyenlőtlenségek vagy a fiskális multiplikátor ciklikus változása. A gazdaságpolitika gyakorlóinak hasonlóképpen mérleget kell vonnia; mit tanultunk a válságkezelésről, és hogyan kerüljünk el egy újabb válságot.

Tanulmányunk összehasonlítja a magyar válságkezelés eszközeit és eredményeit azon európai országok tapasztalataival, amelyek számos tekintetben hasonló gazdaságpolitikai kihívásokkal néztek szembe a válság során. Az összehasonlítás alapja a mediterrán országcsoport (Görögország, Olaszország, Portugália és Spanyolország: ClubMed), amelyben magángazdasági vagy költségvetési okokból a válság egy-egy időszakában hasonlóan gyors gazdaságpolitikai beavatkozás vált szükségessé, ugyanis az addigi gyakorlat fenntarthatatlannak bizonyult.

A mediterrán országok ${ }^{1}$ és Magyarország hasonló gazdasági nehézségekkel néztek szembe. A pénzügyi válság különösen azokat az országokat sújtotta erősen, amelyek makropénzügyi egyensúlyhiánnyal, finanszírozási nehézségekkel küzdöttek, és gazdaságpolitikai mozgásterük korlátozott volt. Nem pontosan ugyanaz volt a válság előtti helyzet valamennyi vizsgált mediterrán országban, de idővel hasonló problémák alakultak ki - noha az euroövezet tagjaiként bizonyos mértékig számíthattak az Európai Központi Bank támogatására. Mind a négy ország bankrendszere nehézségekkel nézett szembe, különösen Spanyolországban és Görögországban alakult ki erős ingatlanpiaci buborék. Olaszország és Görögország az Európai Unió legmagasabb államadóssággal rendelkező államai közé tartozott (Sávai - Kiss 2017). Görögországot, Portugáliát és Spanyolországot a GDP 10 százaléka körüli vagy azt meghaladó folyó fizetési mérleg hiány jellemezte. Görögországban és Olaszországban a nyugat-európai átlagnál számottevően alacsonyabb volt a munkaerőpiaci aktivitás és a foglalkoztatás (1. táblázat).

\footnotetext{
${ }^{1}$ Az elemzés során figyelemmel kell lenni arra, hogy a fenti országok nem kezelhetők minden tekintetben homogén csoportként, ugyanis nemcsak a makrogazdasági instabilitás forrása, hanem a választott eszközök is eltértek bizonyos pontokon.
} 


\section{1. táblázat}

Magyarország és a ClubMed-országok főbb makrogazdasági mutatói a 2008-2010-es évek átlagában

\begin{tabular}{l|c|c|c|c|c} 
& Magyarország & Görögország & Olaszország & Portugália & Spanyolország \\
\hline $\begin{array}{l}\text { Államadósság } \\
\text { (GDP \%-ban) }\end{array}$ & 76,5 & 127,4 & 110,1 & 83,8 & 50,8 \\
\hline $\begin{array}{l}\text { Reál-GDP } \\
\text { növekedése (\%) }\end{array}$ & $-1,7$ & $-3,4$ & $-1,6$ & $-0,3$ & $-0,8$ \\
\hline $\begin{array}{l}\text { Infláció éves átlaga } \\
\text { (\%) }\end{array}$ & 4,9 & 3,4 & 2,0 & 1,1 & 2,0 \\
\hline $\begin{array}{l}\text { Nettó külső adósság } \\
\text { (GDP \%-ban) }\end{array}$ & 54,1 & 86,1 & 42,0 & 79,6 & 86,8 \\
\hline $\begin{array}{l}\text { Költségvetési } \\
\text { egyenleg } \\
\text { (GDP \%-ban) }\end{array}$ & $-4,2$ & $-12,2$ & $-4,1$ & $-8,3$ & $-8,3$ \\
\hline $\begin{array}{l}\text { Munkanélküliségi } \\
\text { ráta (\%) }\end{array}$ & 9,7 & 10,0 & 7,6 & 10,5 & 16,4 \\
\hline $\begin{array}{l}\text { Foglalkoztatási ráta } \\
\text { (\%) }\end{array}$ & 55,4 & 60,4 & 57,6 & 66,5 & 61,1 \\
\hline $\begin{array}{l}5 \text { éves CDS-felár } \\
\text { (bázispont) }\end{array}$ & 272,3 & 311,8 & 139,5 & 114,7 & 112,1 \\
\hline $\begin{array}{l}\text { Folyó fizetési mérleg } \\
\text { (GDP \%-ban) }\end{array}$ & $-2,5$ & $-12,9$ & $-2,7$ & $-10,9$ & $-5,8$ \\
\hline
\end{tabular}

Forrás: Eurostat, MNB

Magyarország a 2002-2008 közötti hibás gazdaságpolitika következtében a válság kitörésekor a mediterrán országokat jellemző valamennyi problémával egyszerre küzdött (Matolcsy 2008). Magyarország rendelkezett az Unió egyik legalacsonyabb foglalkoztatási rátájával, ami egyben a termelés egyik legfőbb korlátja is volt, miközben tartósan magas államháztartási és folyó fizetési mérleg hiánnyal (ikerdeficittel) szembesült. Ennek következtében a magyar gazdaságpolitika fenntarthatatlansága már néhány évvel korábban, 2006-ban felszínre került, és a strukturális reformok hiánya, valamint az akkor indított hibás szerkezetú költségvetési kiigazítás már a válság előtt közel 0-ra csökkentette a magyar gazdaság növekedési ütemét. 2008 végére a magyar gazdaság fundamentumaiban legyengült, gazdaságpolitikai mozgásterében pedig beszűkült állapotban nézett szembe a világméretű pénzügyi és gazdasági krízissel, ami hazánk esetében (is) egy szinkronizált finanszírozási, adósság- és reálgazdasági válságot eredményezett. A magas külső és belső eladósodás, valamint a piaci bizalom hiánya és az állampapírpiac befagyása következtében Magyarország az elsők között kényszerült EU-IMF mentőcsomagért folyamodni.

A globális pénzügyi válság következtében, majd 2011-ben a periféria-országok adósságválsága során a reálgazdasági teljesítmény visszaesett, ami különböző csatornákon keresztül a pénzügyi rendszerben és a pénzpiacok müködésében is 
zavarokat okozott. Általános következmény volt, hogy lecsökkent a hitelezési- és kockázatvállalási hajlandóság, míg a válság által jobban sújtott országokban elhúzódó deflációs kockázat mutatkozott. Eközben az eurozóna egyes tagországainak államkötvényhozama jelentősen megemelkedett, a kereskedelmi banki mérlegekben lévő állampapír-állományon és a nemteljesítő hiteleken elkönyvelt veszteség miatt pedig a bankok visszafogták hitelezési aktivitásukat. A gazdasági válság több helyütt politikai válsággal párosult, és a megfelelő gazdaságpolitikai válaszok megtalálását egyes országokban a sűrú kormányváltások is nehezítették (2010-től 2018 tavaszáig Görögországban hat kormányfő váltotta egymást, Olaszországban pedig öt).

Magyarország 2010 után növekedésbarát költségvetési reformokat, 2013-tól pedig a Magyar Nemzeti Bank (MNB) innovativ, célzott intézkedéseket tartalmazó monetáris politikai fordulatot hajtott végre, aminek következtében válságkezelése eredményesebbnek bizonyult a mediterrán országokénál. Ezzel szemben a mediterrán országok hagyományos megszorító lépésekkel próbálták konszolidálni a költségvetést, a monetáris politikájukat pedig a nem-hagyományos eszközöket csak későn alkalmazó Európai Központi Bank (EKB) határozta meg. Megítélésünk szerint a költségvetési, a foglalkoztatási és a növekedési adatok is egyértelműen mutatják, hogy a fiskális és a monetáris politika összhangjára épülő növekedésbarát magyar válságkezelési modell eredményesebb volt, mint a mediterrán országok hagyományos megközelítésen alapuló intézkedései. A magyar gyakorlathoz hasonló reformok vélhetően az ő esetükben is csökkentették volna a stabilizáció növekedési áldozatát, és így előbb eredményre vezettek volna. Az összehasonlítás során érdemes figyelembe venni, hogy a magyar intézkedéseknek szilárd alapot adott a 2010 óta fennálló politikai folytonosság és stabilitás.

E tanulmányban azt mutatjuk be, hogy miben különbözött a mediterrán országok és Magyarország válságkezelési gyakorlata, és mennyire bizonyultak ezek eredményesnek a kitüzött célok elérését illetően. A második fejezet bemutatja a válságkezelés alapvető dilemmáját, amely szerint gyakran választani kell a gazdasági növekedés élénkítése és a makropénzügyi stabilizáció között, illetve ennek a dilemmának a feloldását. A harmadik fejezet a fóbb költségvetési lépéseket, a negyedik a monetáris politika intézkedéseit ismerteti. Mindkettő mutatja, hogy nagymértékben eltérőek voltak a válságkezelési intézkedések. A monetáris politikát illetően ez részben adottság volt az eurozóna tagjainak számára, hiszen a közös valuta egységes használata nem ad lehetőséget autonóm válságkezelésre, de a fiskális politika önállósága és lehetőségei egészen hasonlóak voltak. Az ötödik fejezet a reformok eredményeit, azaz az elmúlt években elért makrogazdasági helyzetet mutatja. A hatodik fejezetben összegezzük a megállapításokat. 


\section{A válságkezelés alapvető dilemmája: egyensúly vagy növekedés?}

Az instabil helyzetben lévő országok számára a válság során a legnagyobb kihívást az jelentette, hogy intézkedéseikkel a recessziót csillapítsák és a felborult gazdasági - jellemzően költségvetési - egyensúlyt is javítsák. A stabil egyensúlyi helyzetben lévő országok megengedhették maguknak, hogy a költségvetési hiány növelésével enyhítsék a gazdasági visszaesést (tehát anticiklikus politikát folytassanak). Ez volt a jellemző gyakorlat a világ fejlett országaiban, miközben a vizsgált mediterrán országcsoport is e megközelítést próbálta követni (1. ábra). 2010-től azonban az eurozóna gazdaságai a reálgazdasági szempontokat háttérbe szorítva kizárólag a költségvetési egyensúly javítását helyezték előtérbe, azt feltételezve, hogy a hiány csökkentése érdemben nem befolyásolja a gazdasági növekedést. Ez a feltételezés és az ebből eredő prociklikus fiskális politika azonban az európai válságkezelés egyik kulcsfontosságú tévedésének bizonyult.

\section{1. ábra \\ A GDP-arányos költségvetési egyenlegek alakulása Magyarországon és a mediterrán országokban}

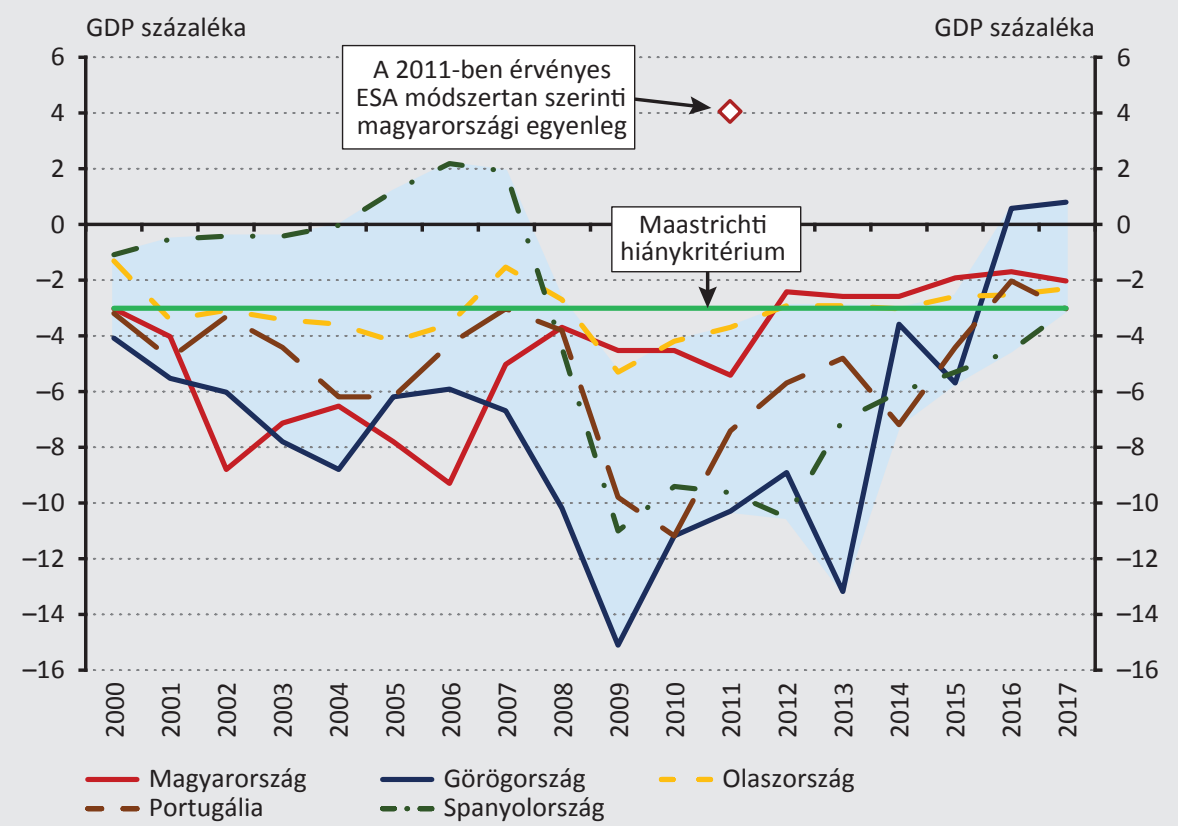

Megjegyzés: A nemzetközi összehasonlításra szolgáló ábrákon a kék sáv a vizsgált mediterrán országok által felvett legalacsonyabb és legmagasabb éves értékek közötti sávot jelöli.

Forrás: Eurostat adatai alapján szerkesztve 
A költségvetési megszoritásokat alkalmazók számottevően alulbecsülték a fiskális multiplikátor recessziós környezetben fellépő erejét. A fiskális multiplikátor annak a mérőszáma, hogy egységnyi változás a kormányzati kiadásokban vagy bevételekben mekkora hatást gyakorol a gazdaság növekedési ütemére. A multiplikátor mértéke azonban más tényezők mellett erőteljesen függ a gazdaság ciklikus helyzetétől és épp recesszió idején a legerősebb (Ilzetzki et al. 2013; Auerbach - Gorodnichenko 2012). Tehát válság idején a gazdaságélénkítő elemeket nem tartalmazó hiánycsökkentő programok olyan mértékben fogják vissza a gazdasági növekedést, hogy az az adóbevételek csökkenésén keresztül a költségvetési konszolidációt is aláássa.

Empirikus adatok is igazolják, hogy a gazdasági visszaesés mértéke a költségvetési megszoritások következtében magasabb lett, mint az elözetes becslések. Blanchard és Leigh (2013) arra az eredményre jutott, hogy a fiskális multiplikátort a Nemzetközi Valutaalap (International Monetary Fund, IMF) számottevően kisebbre becsülte a valóságosnál, és így alábecsülte a költségvetési kiigazítás által okozott recessziót. Vizsgálatuk szerint minél nagyobb volt a fiskális konszolidáció, annál inkább elmaradt a növekedési ütem az előrejelzéstől. Görögország esetében például a GDP növekedése 7 százalékkal volt alacsonyabb 2010-11-ben az előrejelzettnél, míg a költségvetés egyenlege nagyjából megfelelt a várakozásoknak. Eredményeik szerint 0,9-1,7 között lehetett a fiskális multiplikátor értéke az IMF által korábban feltételezett 0,5-ös értékkel szemben.

Megszoritások nélkül a recesszió szinte teljesen elkerülhetö lett volna, egy adóreformmal pedig gyorsítani is lehetett volna a gazdasági növekedést. House et al. (2017) modellezte, hogy az Európai Unió tagállamaiban mennyivel lett volna kisebb a gazdasági visszaesés mértéke megszorító intézkedések (munkát terhelő adók emelése, bérek és nyugdíjak csökkentése) nélkül. Vizsgálatuk szerint a mediterrán zónatag országok (és Írország) esetében a gazdasági kibocsátás potenciális szinttől való visszaesése megszorítások hiányában mindösszesen egy százalék lett volna a ténylegesen bekövetkezett 18 százalékkal szemben (2. ábra). Arra is rávilágítanak tanulmányukban, hogy önálló monetáris politika alkalmazásával még inkább lehetett volna csökkenteni a gazdasági visszaesés mértékét. Az Európai Bizottság (2013) elemzése is alátámasztja, hogy egy növekedésbarát adóreform pozitív reálgazdasági hatásokkal járt volna Spanyolországban és Olaszországban. 


\section{2. ábra \\ Az eurozóna mediterrán tagországai és Írország együttes gazdasági teljesítményének az egyensúlyi helyzethez viszonyított alakulása megszorító intézkedésekkel (tény), illetve megszorítások nélkül (becslés)}

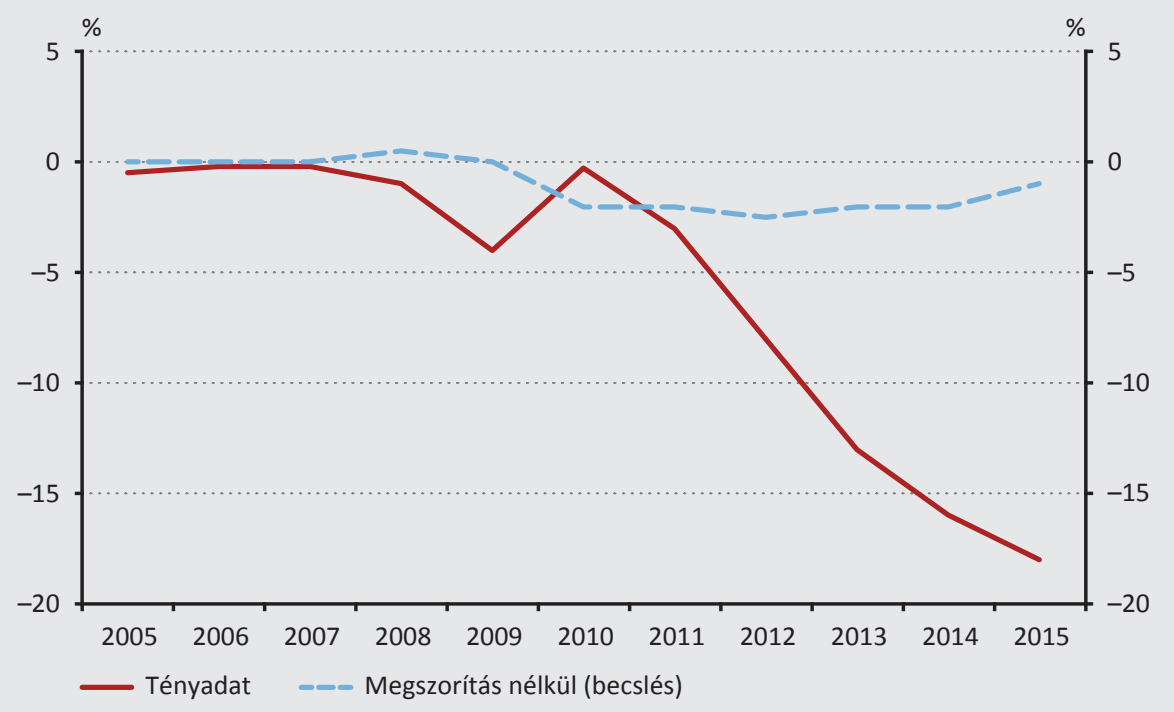

Forrás: House et al. (2017)

Magyarországon 2006-2009 között megszorító jellegü, a válságot erösítő fiskális politika volt jellemző, tehát egy fázissal korábban, mint a mediterrán országokban. 2002 és 2006 között fenntarthatatlanul magas volt a magyar költségvetés hiánya, átlagosan a GDP 7,9 százaléka. A hiány csökkentésére 2006-ban hozott intézkedések rossz szerkezetűek voltak, az adóbevételek emelésén alapultak, ezért hasonlóan hatottak, mint a mediterrán országok későbbi megszorításai (Matolcsy 2015). Az intézkedések eredményeképp 2007-ben, tehát már a válság kitörése előtti évben, a gazdaság növekedési üteme 0 százalék közelébe csökkent, és 2008-ban is 1 százalék alatt stagnált. A globális pénzügyi válság hatására 2009-ben bekövetkező reálgazdasági recesszióra a magyar költségvetés az európai országok többségétől eltérően reagált. Míg több országban a hiány növelésével igyekeztek tompítani a recessziót, addig hazánkban - a korábbi laza fiskális politikával szemben - az IMF-fel és az EU-val kötött hitelprogramok túl szigorú költségvetést kényszerítettek ki. A költségvetési megszorításoknak ez a második hulláma a kiadások csökkentésére fókuszált. Amint a nemzetközi példákon láttuk, válság idején a költségvetési megszorítás különösen erősen fogja vissza a gazdaságot, illetve növeli a recessziót. Ez is hozzájárult ahhoz, hogy a magyar gazdaság 2009-ben az egyik legnagyobb visszaesést szenvedte el az Európai Unióban, mikor 6,6 százalékkal csökkent a GDP. Összességében tehát a magyar gazdaságban már 2006-ban és 2009-ben megtörtént az, ami a mediterrán 
országokban csak 2009 után. A rossz ütemben és szerkezetben végrehajtott költségvetési megszorítás lefékezte a növekedést, illetve növelte a recessziót.

A 2010-ben hivatalba lépő új, polgári kormány olyan költségvetési fordulatot hajtott végre, ami egyszerre csökkentette a hiányt és ösztönözte a gazdasági növekedést. A magyar költségvetési fordulat megoldást kívánt találni arra a közgazdasági dilemmára, mely szerint választani kell az egyensúly és a növekedés között. A dilemma feloldását az új kormány a foglalkoztatás növelésében találta meg, ami a gazdaság növekedésén keresztül egyben az adóalapokat is növeli, és így a költségvetés egyenlegét is javítja. A munkát terhelő adókról a kormányzat a forgalmi, fogyasztási adók felé tolta az adócentralizáció súlyát, és a magyar kis- és középvállalkozások adóit is csökkentette, egyszerűsítette. A költségvetési egyensúlyt kiadási oldalról a munkavállalás ellen ösztönző, indokolatlanul laza szociális transzferek racionalizálása támogatta (a Széll Kálmán-tervek részeként). Az adóreform intézkedéseit, szembeállítva a mediterrán országok lépéseivel, a következő fejezet mutatja be.

Összességében csak Magyarországon javult egyidejüleg a költségvetés egyenlege és a gazdaság növekedési dinamikája 2010 után. A többi mediterrán országban hiába következett be átlagosan a GDP 9 százaléka körüli költségvetési kiigazítás, a költségvetési hiányuk még 2015-ben is meghaladta a 3 százalékos maastrichti küszöböt. Ugyanakkor a megszorítások a gazdasági kilábalást is akadályozták. A mediterrán országok reálgazdasági teljesítménye fokozatosan tovább romlott 2013-ig, és 2016 végéig csak Magyarország gazdasági teljesítménye haladta meg a válság előtti szintet a vizsgált körben (19. ábra).

\subsection{A Laffer-görbe}

A Laffer-görbe azt az elméleti összefüggést illusztrálja, hogy létezik az adókulcsnak egy olyan mértéke, amellyel - adott körülmények között - a legtöbb adóbevétel érhető el a költségvetés számára, az ennél magasabb kulcs esetén azonban a beszedhető adóbevétel összege csökkenni kezd. A Laffer-görbe egy nemlineáris kezdetben pozitiv, majd negatív irányú - kapcsolatot ír le az adókulcs és a realizált adóbevétel mértéke között. ${ }^{2}$

A magas adókulcsok egy ponton túl kimondottan hátrányossá válnak a reálgazdaság és a költségvetés szempontjából egyaránt. A görbe visszahajlása - vagyis a két változó közti kapcsolat pozitívból negatívba fordulása - mögött az a megfigyelés húzódik, hogy a túlzóan magas adóterhelés az adóalap csökkenését eredményezi az ilyenkor megjelenő negatív dinamikus hatások (pl. a munkakínálat csökkenése, a rejtett gazdaság növekedése) miatt. A munkajövedelmek túladóztatása esetén a nettó bér csökkenésével csökken a munkavállalási hajlandóság. Adómértéktől

\footnotetext{
${ }^{2}$ A Laffer-görbe mögötti elmélet korábbra tekint vissza, mint ahogyan azt Arthur Laffer közgazdász használta volna, az 1970-es években azonban ő volt az, aki kiállt az elmélet gazdaságpolitikai alkalmazása mellett, felhívva a figyelmet a túlzott adóterhelés kontraproduktív hatására.
} 
függően a munkakínálat intenzív és extenzív határán egyaránt bekövetkezhet viszszaesés. A tőkejövedelmek túladóztatása esetében pedig a profitabilitás várható csökkenése miatt mérséklődik a vállalati beruházási hajlandóság.

A gazdasági szereplök adóterhelésének mértéke válság idején különösen releváns kérdés. Kereslethiányos, illetve likviditáskorlátos gazdasági környezetben jellemzően nagyobb a fiskális multiplikátor, mert a gazdasági szereplők egyéb pénzügyi forrás hiányában érzékenyebben reagálnak a fiskális politika intézkedéseire. Ebből adódóan a jövedelemre rakódó túlzó adóteher vagy annak növelése fokozottan kedvezőtlenül érinti a gazdasági növekedést, valamint az adóalapokon keresztül a költségvetés pozícióját. A válság tompítása céljából ezért növekedésösztönző, vagyis adótehercsökkentő intézkedésekkel egybekötött költségvetési racionalizálás indokolt, amely a kedvező dinamikus hatásokon keresztül a gazdaság mellett a költségvetési egyenleget is stabilizálja.

Az empirikus tapasztalatok szerint a Laffer-görbe csúcspontja 50-60 százalék körül helyezkedik el. A válság elött a magyar adóék a negativ szakaszban lehetett, de mára kedvezőbb tartományba süllyedt. A Laffer-görbe alakja (magassága, meredeksége és ferdesége) országonként és időszakonként különböző lehet, ugyanis az adott nemzetgazdaság adórendszere, az adóhatóság múködése, az adóelkerülés mértéke, az adóköteles jövedelem rugalmassága azt nagymértékben befolyásolja. A nemzetközi tapasztalatok azt mutatják, hogy a görbe csúcspontja nagyjából 50-60 százalék körüli adókulcsnál található a munkát terhelő adók esetében (Trabandt Uhlig 2012). Ennek tükrében érdemes megvizsgálni azt, hogy Magyarország a görbe melyik szakaszán helyezkedett el 2010-et megelőzően, illetve jelenleg. 2009-ben a magyar átlagos adóék mértéke az átlagbérnél 53 százalék volt, míg a marginális adóék mértéke a 70 százalékot is meghaladta. Utóbbi a 2000-es évek közepén 75 és 80 százalék között is alakult. Ezzel szemben az átlagos adóék mértéke mára 45 százalékra csökkent, sőt a célzott csoportokban - a családi adóalap-kedvezmény és a Munkahelyvédelmi Akcióterv (MAT) bevezetésével és bővitésével - még ennél is kisebb (20-43 százalék). A célzott társadalmi csoportok (gyermeket vállaló családok, valamint a munkaerőpiaci szempontból veszélyeztetettebbek) alacsony mértékű adóztatása összhangban van a kormányzat társadalompolitikai célkitűzéseivel, prioritásaival (demográfiai folyamatok javítása, teljes foglalkoztatás). A marginális adóék mértéke megegyezik az átlagos adóék mértékével az egykulcsos arányos személyijövedelemadó-rendszer bevezetése óta (3. ábra). 


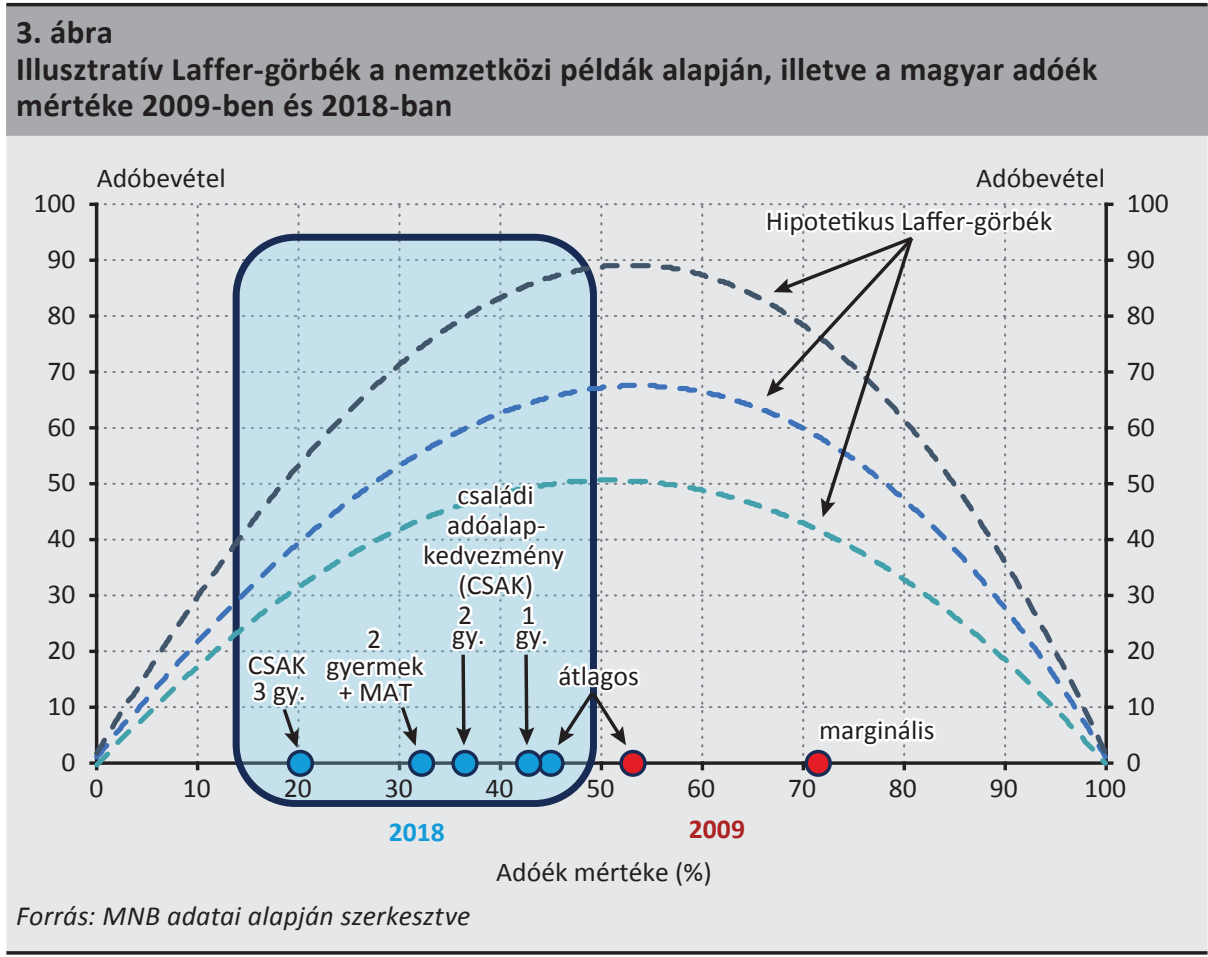

\section{A magyar válságkezelés: egyensúly és növekedés}

A 2010 utáni magyar költségvetési politika innovativ, növekedésbarát utat választott a válság kezelésére (Matolcsy 2015; Kolozsi et al. 2017). Az új gazdasági vezetés gyorsan felismerte, hogy rendkívüli körülmények között csak rendkívüli, célzott, nemkonvencionális eszközök alkalmazása vezethet eredményre. A hagyományos, megszorító intézkedésekre épülő költségvetési politika ugyanis megfojtja a gazdasági növekedés lehetőségeit - különösen válságok idején (Eyraud - Weber 2013).

Az adórendszer átalakításának fö célja egy olyan adóstruktúra kialakítása volt, amely biztosítja a költségvetési egyensúlyt és támogatja a gazdasági növekedést is - e két cél egyidejü teljesíthetősége a foglalkoztatás bövítésén alapult (Palotai 2017). A foglalkoztatási ráta alacsony szintje valamennyi vizsgált gazdaságban strukturális probléma volt, de még jelentősebb társadalmi problémává vált a munkanélküliség magas szintje a válság alatt. A 2000-es évek közepén a magyar aktivitási és foglalkoztatási ráta a második legalacsonyabb volt az EU-ban (2003-2007 átlagában előbbi 61, utóbbi 57 százalék), amit jelentős részben a munkát terhelő adók magas szintjének és a túlságosan laza szociális rendszernek lehetett tulajdonítani. A magyar gazdaság számára ez tartós károkat okozott, ugyanis a megfelelő mennyiségű 
és minőségű munkaerő aktív rendelkezésre állása a versenyképesség és sikeres felzárkózás egyik alappillére.

A foglalkoztatottak számának növelése és a munkanélküliség visszaszorítása a magyar gazdaságpolitika és adóreform prioritása lett, legfontosabb eszköze pedig az adószerkezet súlypontjának elmozdítása volt a munkát terhelő adók felől a fogyasztást terhelő adók irányába (4. ábra) (Szoboszlai et al. 2018). Amellett, hogy a személyi jövedelemadó csökkentése ösztönzi a munkavállalást, az ilyen típusú adóátrendezés javítja a külső versenyképességet is. A munkát terhelő adók csökkentésével ugyanis olcsóbbá válik az exportra termelés, míg az import - a forgalmi adók növelésével - megdrágul, ami összességében növeli a nemzetgazdaság exportpiaci versenyképességét ${ }^{3}$ (OECD 2010; Prammer 2011). A költségvetés egyensúlyát az adóátrendezés mellett az ágazatspecifikus válságadók biztosították, amelyeket a kormány a nagyobb teherviselő képességű szolgáltató ágazatokra vetett ki (bank-, biztosítási, energetikai, távközlési és kiskereskedelmi szektor). Megkezdődtek az első lépések az adóbeszedés hatékonyságának növelése érdekében is, ami a válságból való kilábalással együtt teljesedett ki. Az adórendszer szerkezeti átalakítása 20102013 között lezajlott, amit később még parametrikus finomhangolások követtek.

\section{4. ábra \\ A 2010 utáni magyar adóreformok becsült statikus, kumulált költségvetési hatása adótípusok szerint bontva}

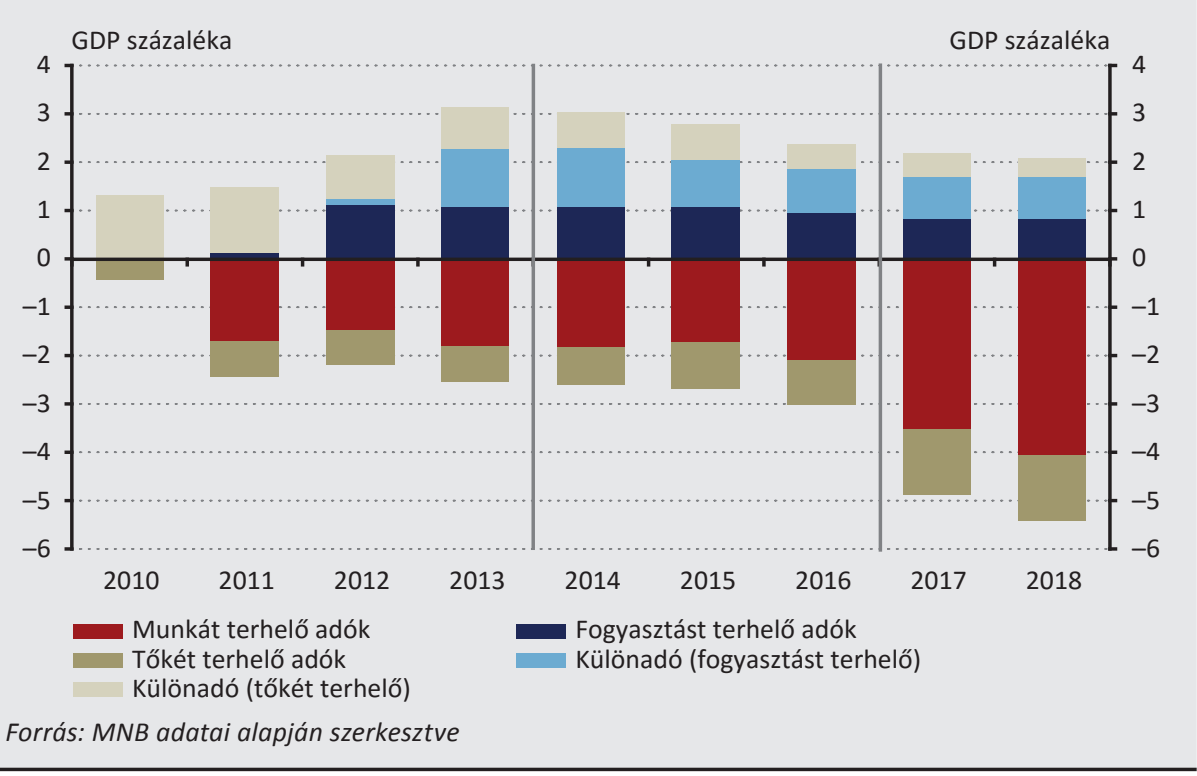

\footnotetext{
${ }^{3}$ Ezt a szakirodalom ún. „fiskális leértékelésnek" nevezi.
} 


\subsection{A munkát terhelő adók rendszerének átalakítása}

A munkát terhelő adók csökkentésének legnagyobb horderejú lépése az egykulcsos, arányos személyijövedelemadó-rendszer bevezetése volt, amelynek szintje alacsonyabb lett, mint a korábbi legalsó kulcs. A progresszivitás több lépésben történő megszüntetése (amelynek része volt az adójóváírás és a szuperbruttósítás intézményének teljes kivezetése is $)^{4}$ elismerte és ösztönözte a többletmunkát és többletteljesítményt, tehát növelte a már munkapiacon lévők effektív munkakínálatát (az intenzív határon is hatva a munkakínálat rugalmasságára). Emellett mérsékelte a jövedelemeltitkolásra való hajlandóságot a munkavállalói és a munkáltatói oldalon egyaránt.

A munkahelyvédelmi akcióterv az egyik legfontosabb, a foglalkoztatást érdemben támogató, célzott program, amely a munkaerőpiac keresleti oldalát erősítette 2013tól. A MAT keretében bevezetett célzott munkáltatói járulékkedvezmények jelentős támogatást jelentenek a munkaerőpiaci szempontból veszélyeztetettebb csoportoknak (25 év alattiak és 55 év felettiek, gyed-/gyesről visszatérő anyák, szakképzetlenek, tartósan munkanélküliek, valamint a mezőgazdasági munkakörben foglalkoztatottak). A leginkább kedvezményezett csoportokban a havi jövedelem első 100 ezer forintjáig a szociális hozzájárulási adó teljes egészét elengedte a program, másutt mintegy a felét. A foglalkoztatás általános növekedése mellett az érintett csoportokban különösen nagymértékben, 40 százalékkal emelkedett a foglalkoztatás a program bevezetése óta, és összesen mintegy 900 ezer munkavállalót foglalkoztatnak a kedvezményrendszer keretein belül.

A családi adóalap-kedvezmény (CSAK) bevezetése elsősorban családpolitikai intézkedés a hosszú távú demográfiai kihívás kezelésére, de jellegéből adódóan támogatja a munkakínálat növelését is. A gyermek(ek) után járó állami dotáció ugyanis nem alanyi jogon jár, hanem annak érvényesítési feltétele az, hogy a kedvezményezett szülő bejelentett, legális jövedelemadó-alappal rendelkezzen. A támogatás munkavállaláshoz kötése ösztönöz a munkaerőpiacon való aktív részvételre, valamint az eltitkolt jövedelmek bevallására.

\footnotetext{
${ }^{4}$ Az adójóváírás olyan, alanyi jogon igénybe vehető adókedvezmény volt, amely a fizetendő személyi jövedelemadó mértékét csökkentette. A támogatás fokozatos lecsengetése érdemben emelte a marginális adóéket, ami így a 2010. évi átlagbér felett már 60 százalék fölé emelkedett, míg az adójóváírás nullára csökkenésével és a személyi jövedelemadó felső kulcsának belépésével a marginális adókulcs mértéke csaknem 70 százalék volt. Az adójóváírás rendszere 2012-ben teljesen megszüntetésre került, ami hozzájárult a személyijövedelemadó-rendszer egyszerűsítéséhez, a marginális adókulcs csökkentéséhez.

A szuperbruttósítás a munkát terhelő adók növelésének egy „rejtett” formája volt, ugyanis a jövedelemadókulcsok helyett az adóalap került adminisztratív úton megemelésre. A rendszer a munkáltatói járulékterhek 2010-es mértékével, 27 százalékkal növelte a személyi jövedelemadó alapját, amely így minden jövedelmi szintnél egységesen emelte az átlagos terhet. A szuperbruttósítás 2010. január 1-jétől került bevezetésre, amely két lépcsőben, 2013-ra teljesen kivezetésre került, hozzájárulva az élőmunkát terhelő adók csökkentéséhez.
} 
A mediterrán országokban a személyi jövedelemadó erősen progresszív szerkezetét Magyarországgal ellentétben nem alakították át. A válság előtt Magyarországhoz hasonlóan a mediterrán országok is többkulcsos, progresszív személyijövedelemadó-rendszert müködtettek: Görögországban 3, Olaszországban 5, Portugáliában 7, Spanyolországban 4 kulcsos volt az adórendszer. Míg 2010 után a magyar jövedelemadó rendszer progresszivitása kivezetésre került, és helyette az arányosabb közteherviselést elősegítő egykulcsos rendszer lépett életbe, addig a mediterrán országokban megmaradt a többkulcsos progresszív személyijövedelemadó-rendszer. A válságot követően Görögországban 10, Olaszországban 6, Portugáliában 7, Spanyolországban pedig 5 kulcsos rendszert hoztak létre, főként a különadók bevezetése következtében. A módosítások nemcsak a rendszer progresszivitását és bonyolultságát növelték, hanem a munkára rakódó terhek mértékét is (2. táblázat).

\section{2. táblázat}

Magyarország és a mediterrán országok személyijövedelemadó-rendszere a válság előtt (2007-ben) és után

\begin{tabular}{l|c|c|c} 
& $\begin{array}{c}\text { Személyijövedelemadó- és } \\
\text { különadó-kulcsok száma }\end{array}$ & $\begin{array}{c}\text { Szja-kulcsok } \\
\text { a válság elött }\end{array}$ & $\begin{array}{c}\text { Szja-kulcsok az } \\
\text { intézkedések után }\end{array}$ \\
\hline Magyarország & $2+1$ kulcs $->1$ kulcs & $18 \%$ és $36 \%+4 \%$ & $15 \%$ \\
\hline Görögország & 3 kulcs $->4+6$ kulcs & $29 \%-40 \%$ & $22 \%-45 \%+10 \%$ \\
\hline Olaszország & 5 kulcs $->5+1$ kulcs & $23 \%-43 \%$ & $23 \%-43 \%+3 \%$ \\
\hline Portugália & 7 kulcs $->5+2$ kulcs & $10,5 \%-42 \%$ & $14,5 \%-48 \%+5 \%$ \\
\hline Spanyolország & 4 kulcs $->5$ kulcs & $24 \%-43 \%$ & $19 \%-45 \%$ \\
\hline
\end{tabular}

Megjegyzés: A táblázatban $a+{ }_{\text {„y }} x$ ” százalékos értékek az SZJA különadókat jelzik. Az intézkedések után jelölt különadók a lehetséges legmagasabb értéket mutatják.

Forrás: OECD (2017) adatai alapján szerkesztve

A munkát terhelő adókat csökkentő magyar kormányzati intézkedések következtében a marginális adóék (az egységnyi többletjövedelmet sújtó adóteher) jelentősen csökkent a válságot követően. Ezzel szemben a mediterrán térségben stagnált vagy emelkedett a többletjövedelem adókulcsa (5. ábra). 


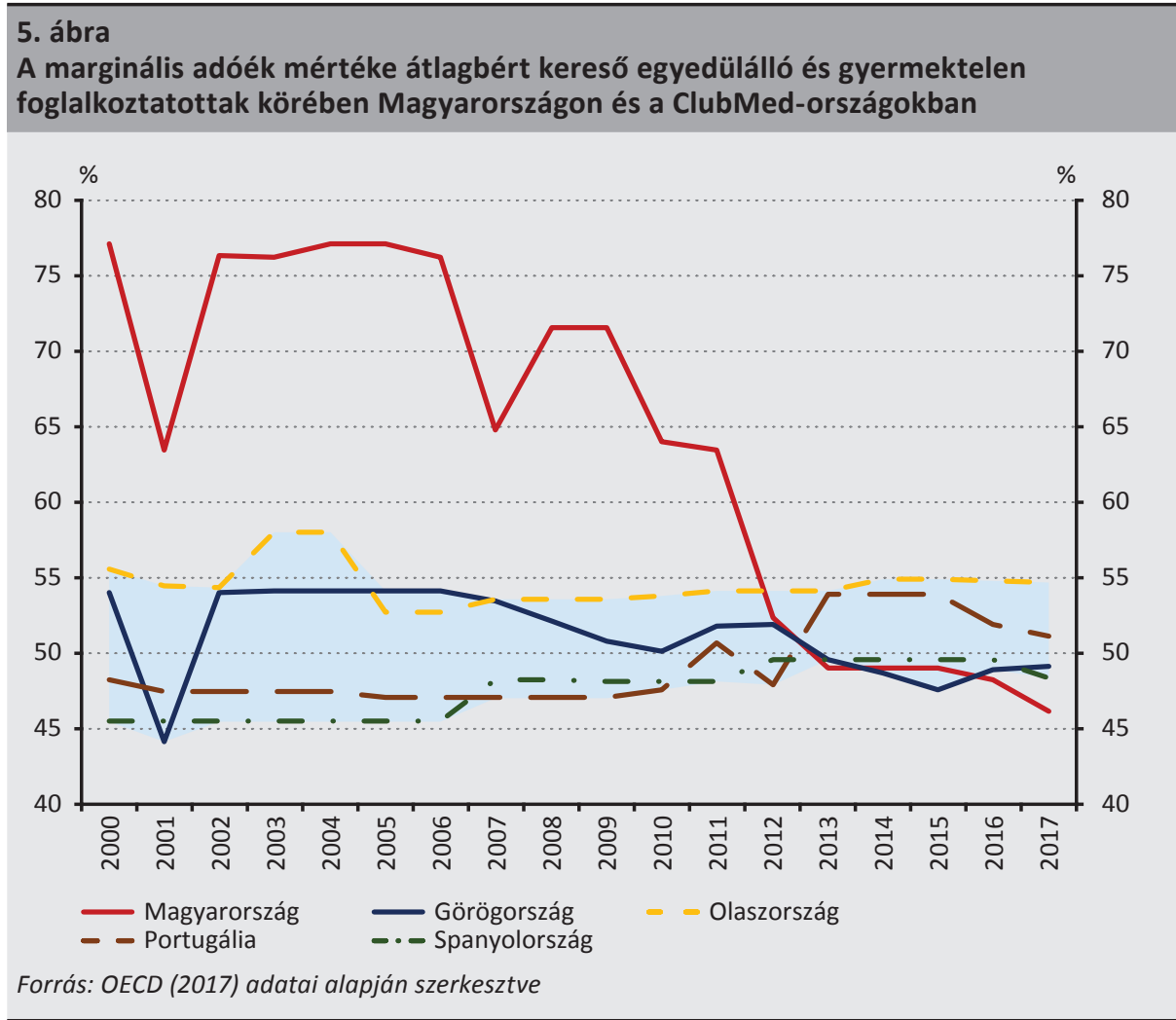

A személyi jövedelemadó (szja) 2010 utáni csökkentése az adószerkezet változásában jól megfigyelhető. 2010-et megelőzően a magyar szja-bevétel a teljes hazai adóbevétel arányában 18-19 százalék körül alakult, ami a viszonyítási alapnak tekintett mediterrán országok alkotta sáv közepén helyezkedett el. 2011-re azonban a magyar érték 13 százalék, 2016-ra pedig 12 százalék közelébe csökkent, aminek következtében a hazai szja-bevételek aránya vált a legalacsonyabbá. Ezzel szemben a mediterrán zónatagok szja-bevételi mértékei a magyar trenddel ellentétes mozgást mutatnak: a válságidőszakban stagnáltak vagy nőttek. Olaszország a vizsgált körben kiugróan nagy mértékben támaszkodik a személyi jövedelemadóra a költségvetés finanszírozásában (6. ábra). 


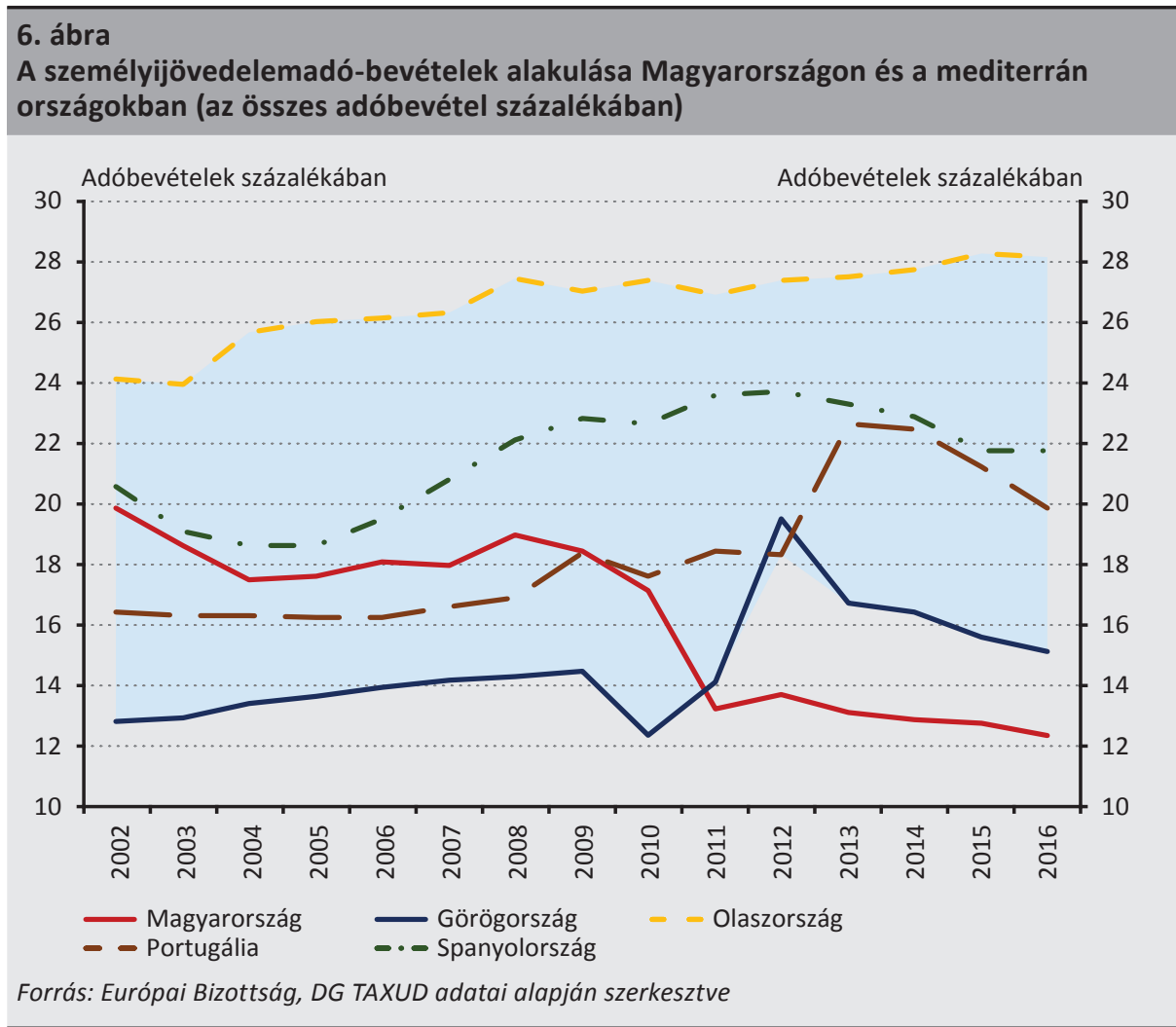

\subsection{A társasági adók alakulása Magyarországon és a mediterrán országokban}

A magyar gazdaságpolitika a hazai mikro-, kis- és közepes vállalkozások adóterheinek csökkentésén keresztül is érdemi lépéseket tett a foglalkoztatás és a munkahelyteremtés ösztönzése, valamint a vállalati profitabilitás és tökeakkumuláció növelése érdekében. A kkv-szektor kiemelt támogatását többek között az is indokolja, hogy Magyarországon a foglalkoztatottak mintegy kétharmada ehhez a szektorhoz kötődik.

Már 2010-ben jelentősen növelte a kormányzat a kedvezményes társasági adókulcsra (tao) jogosult kkv-k körét. 2010 második felétől 50 millió forintról 500 millió forintra emelkedett a kedvezményes, 10 százalékos kulcs alkalmazhatóságára vonatkozó árbevételi sávhatár (felette 19 százalékos kulccsal adóztak), aminek eredményeképpen jelentősen kibővült az alacsony tao-kulcs alá tartozó vállalatok köre. 2017-től egységesen 9 százalékra csökkent a társasági adó kulcsa, ami egyben az Európai Unió legalacsonyabb ilyen típusú vállalati adóterhelésének számít. Míg a 2010-ben hozott intézkedés főleg a mikro-, kis- és közepes vállalatoknak nyújtott 
érdemi adókönnyítést, addig a 2017-es adócsökkentés elsősorban a tőkevonzást és nagyvállalati versenyképességet támogatja (Mosberger 2017).

A mediterrán országok - a személyi jövedelemadóhoz hasonlóan - a társasági adókulcs jelentős csökkentésének eszközével sem éltek a válság során (7. ábra). Portugáliában a válság előtt átlagosan 26,5 százalékos adókulcs a válság végére közel 30 százalékosra nőtt. Görögországban azonos időszakban a társasági adó mértéke 25-ről 29 százalékra növekedett. A másik két vizsgált mediterrán országban, Spanyolországban és Olaszországban a tao kulcsa ugyan némileg csökkent, de mértéke továbbra is magas maradt (a spanyoloknál 25, az olaszoknál 27,8 százalékos).

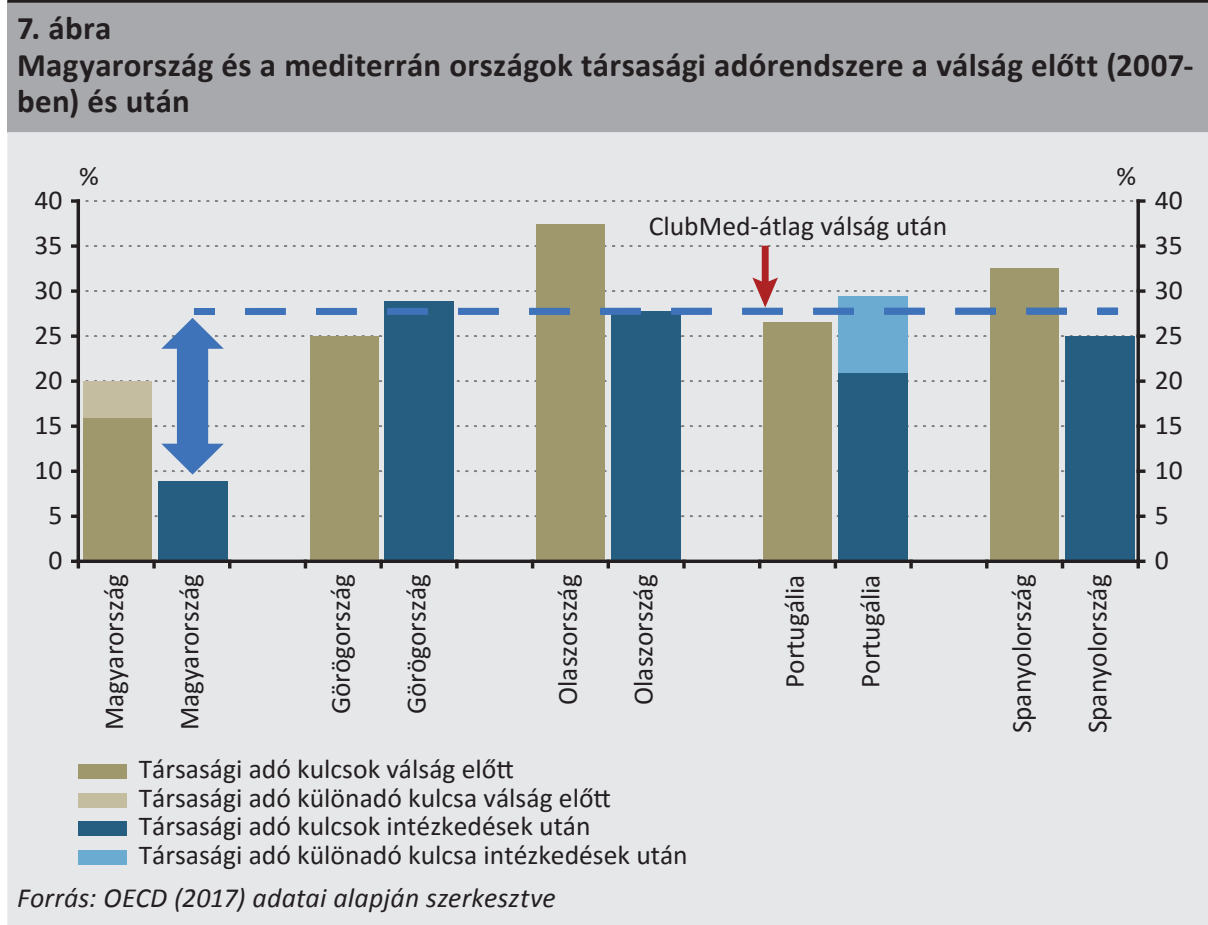

Két fontos, célzott adózási forma, a kisadózó vállalkozások tételes adója (kata) és a kisvállalati adó (kiva) 2013-as bevezetésével tovább csökkent és egyszerüsödött a magyar kkv-szektor tőkejövedelmének adóterhelése. E célzott kisvállalati adózási formák népszerűsége fokozatosan teret nyert, hiszen ezek keretében egyszerūsített, kevesebb adminisztrációt igénylő módon, valamint kedvezményesen adózhatnak az adóalanyok, kiváltva ezzel egyszerre több más adónem bevallási és befizetési kötelezettségét. Különösen egyszerű a kisadózó vállalkozások tételes adója, ami havi fix összegű adó a legkisebb vállalkozások részére (főállású kisadózó esetén havi 50000 forint évi 12 millió jövedelemig). A kata megfizetésével az adóalany mentesül 
a vállalkozói személyi jövedelemadó, a társasági adó, az osztalékalap utáni adó vagy átalányadó, továbbá a személyi jövedelemadó, az egyéni járulékok, az egészségügyi hozzájárulás, valamint a szociális hozzájárulási adó és szakképzési hozzájárulás megfizetése alól, tehát számottevően mérséklődnek az adminisztrációs terhei. A másik új adónem, az úgynevezett kisvállalati adó a némileg nagyobb vállalkozások számára lett tervezve, és a bevezetésekori 16 százalékról 13 százalékra csökkentett adókulcsával három hagyományos adót vált ki: a társasági adót, a munkáltatói járulékot (szociális hozzájárulási adó) és a szakképzési hozzájárulást.

Az intézkedések következtében a tökét terhelö adók mértéke csökkent Magyarországon, így több jövedelem maradt a vállalkozásoknál beruházásra, létszámbővítésre. A tőkét terhelő adók GDP-arányos mértéke Magyarországon a globális válság előtt és után is alacsonyabb a mediterrán országokénál. 2010-től kezdődően a tőkejövedelmek adóterhelése Magyarországon csökkent, míg a mediterrán országok GDP-arányos tőketerhei fokozatosan emelkedtek (8. ábra).

\section{8. ábra}

\section{Tőkét terhelő adók a GDP arányában Magyarországon és a mediterrán országokban}

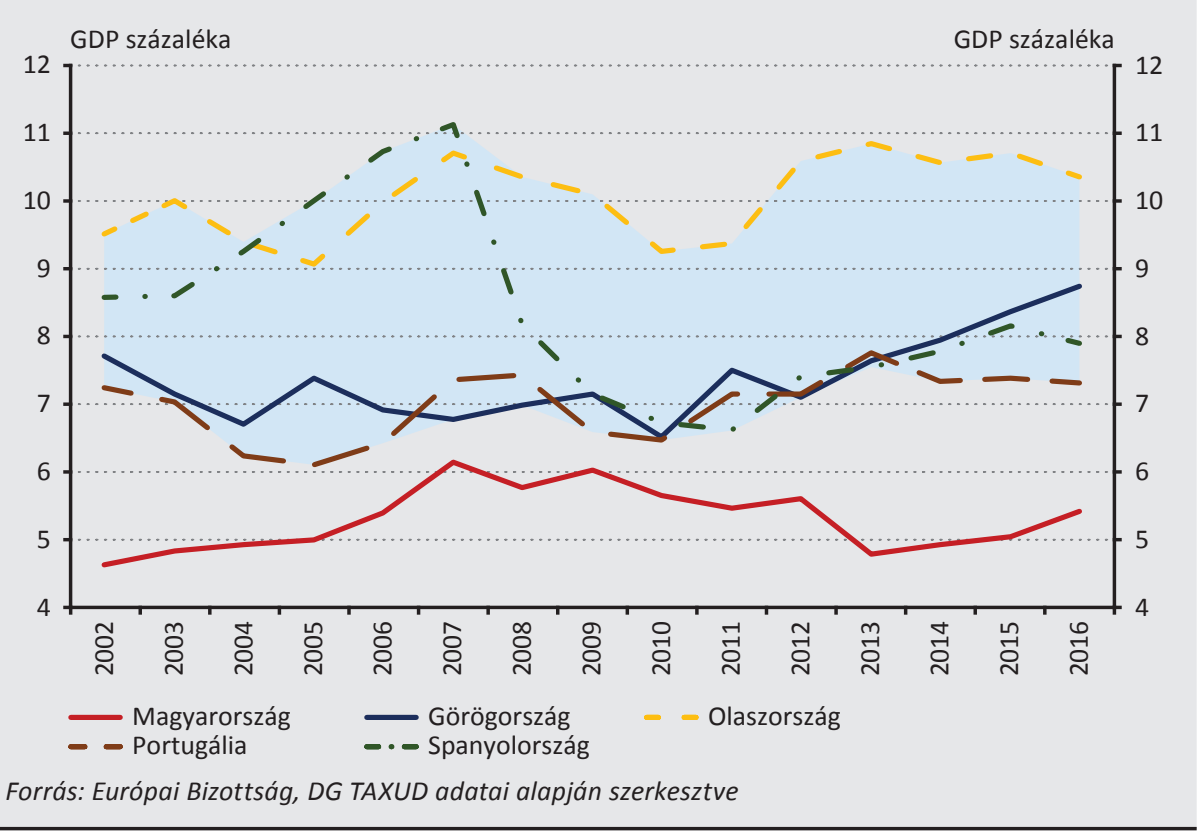




\subsection{Forgalmi adók és szektorális különadók a költségvetési egyensúly megte- remtéséhez}

A foglalkoztatást és a növekedést ösztönző lépések finanszírozásához pótlólagos költségvetési források bevonására is szükség volt Magyarországon, mivel a reformintézkedések első néhány éve jellemzően még kevesebb költségvetési haszonnal, mint költséggel jár. A kieső költségvetési források biztosításának három lehetséges módja jöhetett szóba:

- hagyományos megszorító intézkedések bevezetése;

- magas hiány, növekvő külső eladósodás;

- forgalmi adók növelése és alternativ, újszerü eszközök (szektorális különadók) alkalmazása.

A magas hiány fenntartása, vagy a megszorító intézkedések a 2010 utáni gazdaságpolitika egyensúlyjavitó és gazdaságösztönző céljaival ellentétesek voltak. Az addicionális költségvetési mozgástér megteremtésének eszközét így a forgalmi adók növelése és a szektorális különadók bevezetése jelentette. A fogyasztást terhelő adók kevésbé torzítják a gazdasági szereplók megtakarítási és beruházási döntéseit, valamint megfelelően széles adóalappal rendelkeznek, ugyanis a munkaerőpiaci szempontból inaktívakat is adózás alá vonja (Európai Bizottság 2011). A szektorális különadók alkalmazását pedig a nagyobb tőkeerővel és alacsonyabb effektív adókulccsal rendelkező ágazatok (bankszektor, energetikai szektor, kiskereskedelmi szektor) a háztartásokét számottevően meghaladó teherviselő képessége indokolta. A háztartások rendelkezésre álló jövedelmének csökkentése a magas fiskális multiplikátor miatt kontraproduktív lett volna a válság éveiben, amint azt a mediterrán országok példája is mutatta.

A forgalmi adók emelésével a magyar adószerkezet érdemben eltolódott a fogyasztást terhelő adók irányába (9. ábra). A legnagyobb lépést a 25 százalékos áfakulcs 27 százalékra növelése jelentette. A fogyasztást terhelő adók arányának növekedéséhez az is hozzájárult, hogy 2013-tól javarészt kivezetésre kerültek az ágazati különadók, és helyettük új, fogyasztási, forgalmi típusú adónak tekinthető adók (például biztosítási adó, távközlési adó, pénzügyi tranzakciós illeték) kerültek bevezetésre. ${ }^{5}$

\footnotetext{
${ }^{5}$ Az Eurostat a különadók közül a fogyasztást terhelő adók közé sorolja a pénzügyi tranzakciós illetéket, a reklámadót, a baleseti adót, a biztosítási adót, a távközlési adót és a népegészségügyi termékadót.
} 


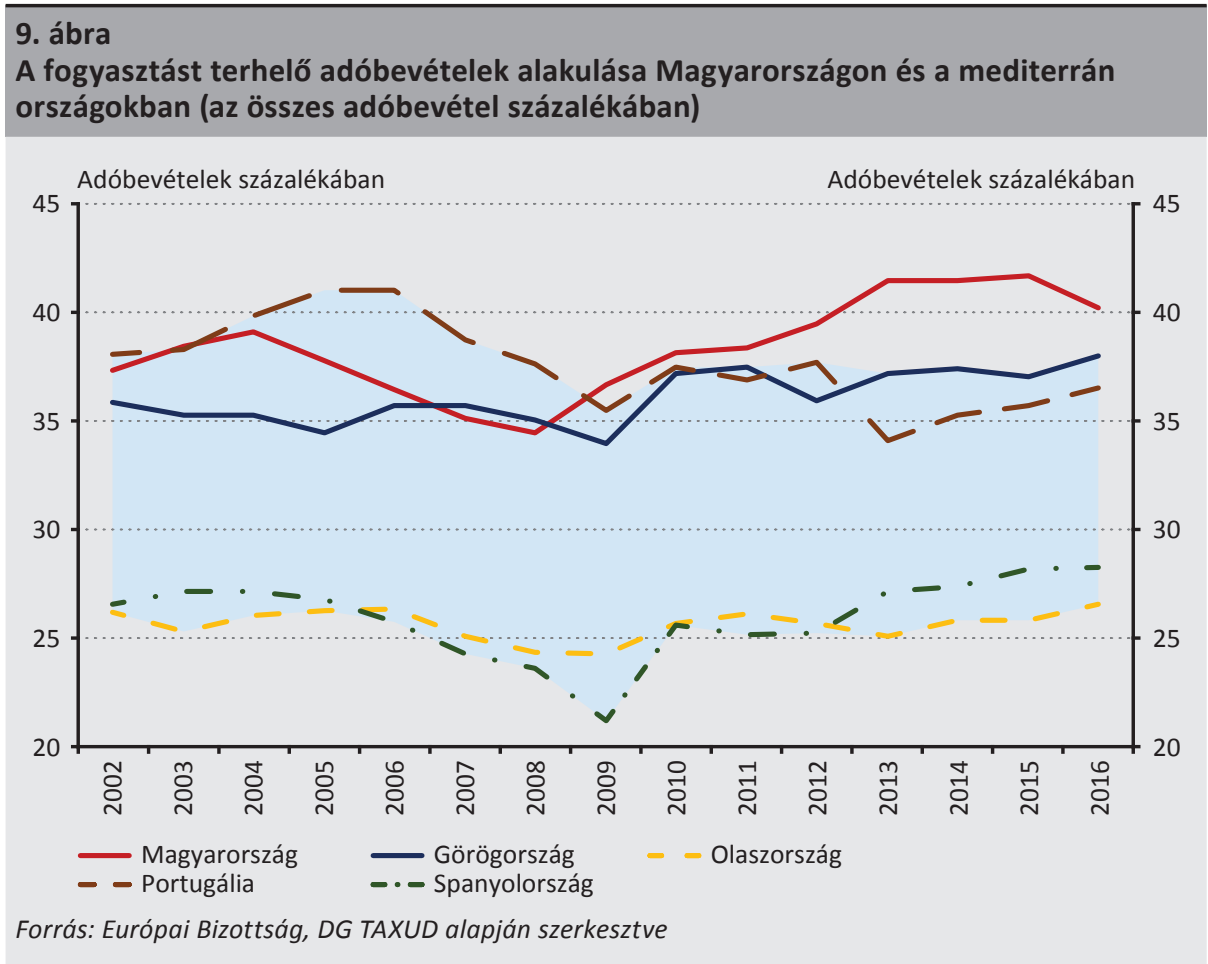

Az adóbevételeket az adókulcsok emelése nélkül növelték az adóelkerülés csökkentése irányába tett hatékony lépések. A legjelentősebb gazdaságfehérítő intézkedés a kiskereskedelmi szektor pénztárgépeinek adóhivatali rendszerrel való online összekötése, majd annak többlépcsős kiterjesztése volt. Ennek köszönhetően már 2016ra több mint 200 ezer ilyen ellenőrző regiszter működött (Szalai - Kolozsi 2016). A gazdaság fehéredéséhez szintén érdemben hozzájárult az Elektronikus Közúti Áruforgalom Ellenőrző Rendszer (EKÁER) ${ }^{6}$ bevezetése, valamint a fordított áfa-kulcsok alkalmazása számos területen. Mindezek eredményeképpen 2013 után szignifikánsan mérséklődött Magyarországon a rejtett gazdaság mértéke. Az Európai Bizottság számításai szerint 2013-ról 2015-re 21 százalékról 14 százalékra csökkent az áfa-adórés ${ }^{7}$ mértéke Magyarországon (Európai Bizottság 2017). Emellett az adóbevétel és a becsült adóalap hányadosaként számítható effektív áfa-kulcsra vonatkozó becslés is a gazdaság fehéredését mutatja. Az effektív kulcs 2013 és 2015 között több mint 2 százalékponttal emelkedett az áfa törvényi kulcsának változtatása nélkül (10. ábra).

\footnotetext{
${ }^{6}$ Az EKÁER a szállítmányozás hazai tevékenységének gazdasági fehérítését és az élelmiszerbiztonság növelését célzó kormányzati infrastruktúra, amelynek kidolgozására a Széll Kálmán Tervvel összhangban került sor, üzemeltetése pedig 2015. január 1-jétól léptett hatályba. A szállítással kapcsolatos adatokat egy központi elektronikus rendszerben kell rögzíteni még a fuvarozás előtt, így erősíti a jogkövető piaci szereplők pozícióját, az áruforgalom átláthatóságát, valamint lehetővé teszi az adóelkerülők kiszűrését.

${ }^{7}$ A rejtett gazdaság becslésének egyik eszköze az áfa-adórés számítása, ami a potenciálisan beszedhető és a ténylegesen beszedett áfabevételek különbsége.
} 


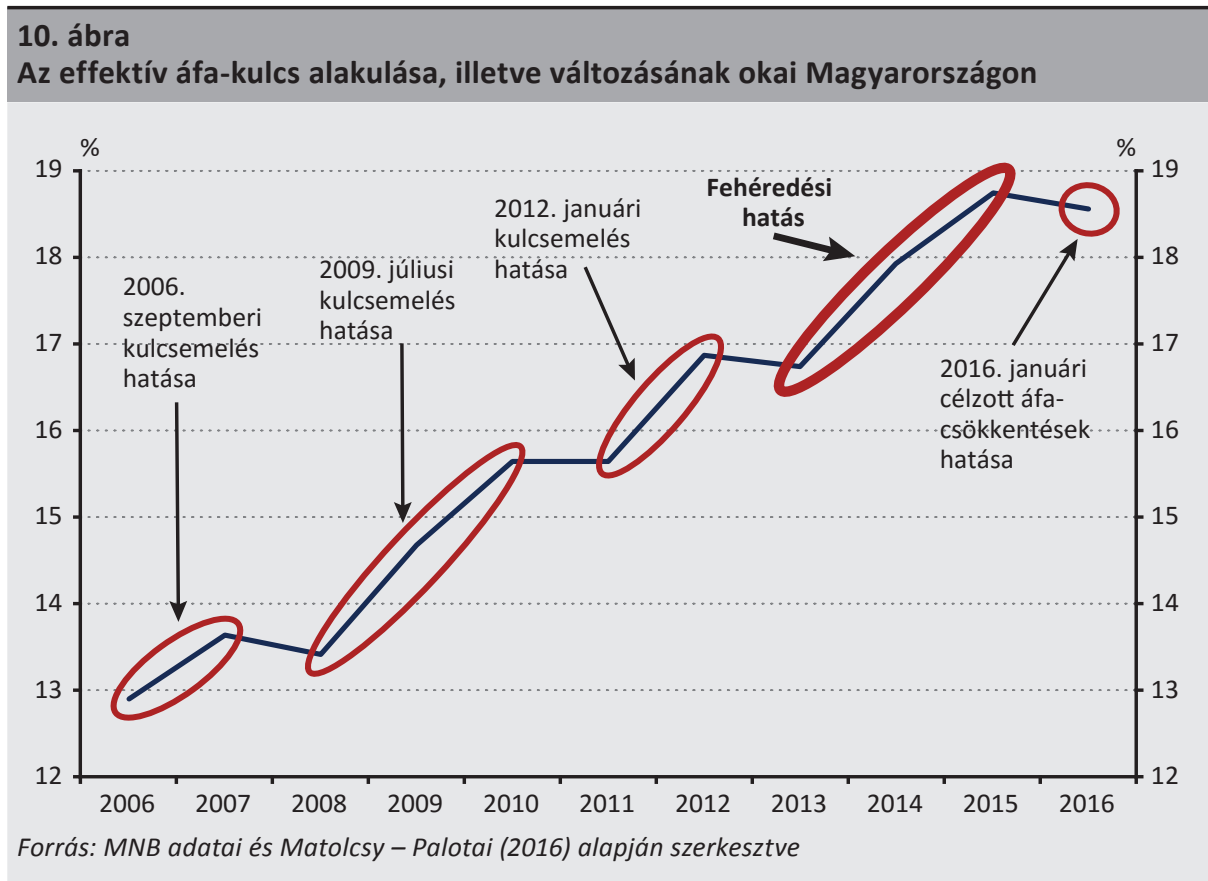

\subsection{Strukturális reformok a megszorító intézkedésekkel szemben}

A költségvetés kiadásainak átalakitása során is más utat járt Magyarország és a mediterrán országcsoport. A költségvetés stabilizálásának hagyományos eszköze a kiadások csökkentése. Válság idején, amikor a költségvetési megszorítások különösen erősen hatnak a gazdaságra az általános kereslet- és forráshiány miatt, az ilyen intézkedések a recesszió erősödésének irányába hatnak. Ha a magánszektor kereslete nem elég erős, hogy ellensúlyozza a költségvetési kereslet csökkenését, akkor a recesszió tovább mélyül. Ezért a kiadások csökkenését strukturális reformokkal kell összekötni, amelyek a kiadások mellett az erőforrások hatékonyabb kihasználását eredményezik.

Magyarországon a költségvetési kiadások csökkentése a munkaerőpiacot élénkitő versenyképességi reformokkal volt összekötve. A 2010 előtti indokolatlanul laza szociális rendszer magas költségvetési kiadásokat és alacsony munkaerőpiaci részvételt eredményezett. A Széll Kálmán-tervek keretein belül végrehajtott reformok célzottan úgy csökkentették a kiadásokat, hogy egyben növeljék a munkaerőpiaci aktivitást. Sor került a korkedvezményes nyugdíjba vonulás lehetőségeinek jelentős korlátozására, a rokkantnyugdíjak jogosultsági feltételeinek felülvizsgálatára, a munkanélküli segélyek időtartamának és összegének mérséklésére. Ennek eredményeként Magyarországon jelentősen csökkent a korhatár alatti nyugellátásban részesülők száma (11. ábra) és nőtt az aktivitási ráta, ami a munkaerőkínálat és a tényleges nyugdíjba vonulás növelése mellett hozzájárult a költségvetési egyenleg stabilizálásához is. 


\section{1. ábra}

A korhatár alatti nyugellátásban részesülők száma, valamint az ellátásukra fordított költségvetési kiadások alakulása

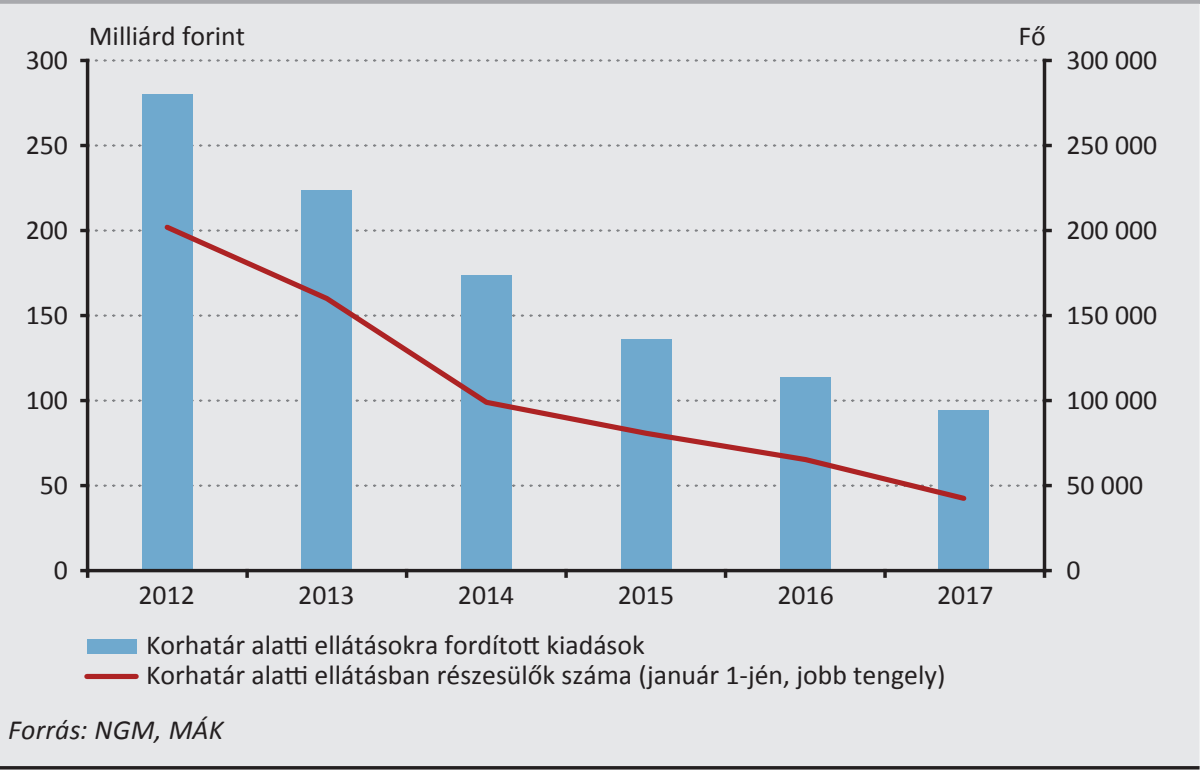

A magánnyugdijpénztári rendszer reformja nemcsak a költségvetés stabilitásához járult hozzá, hanem egy gyenge hatékonysággal müködő, pazarló rendszert szüntetett meg. A pénztárak a rendszerszinten garantált bevételeik nagy részét az éppen a számukra átengedett járulékbevételek kiesése miatt növekvő adósságot finanszírozó állampapírokba fektették (Banai - Palotai 2018). Gyenge verseny és magas múködési költségek jellemezték a szektort, ami évente 1-1,5 százalékponttal növelte a költségvetés hiányát. A kötelező magánnyugdíjpénztári tagság megszüntetése, az állami rendszerbe való visszalépés lehetőségének megnyitása és ösztönzése nagymértékben támogatta a 3 százalék alatti költségvetési hiány elérését és az államadósság tartósan csökkenő pályára állítását.

A strukturális reformok eredményeképp elért megtakaritások egy részét a közfoglalkoztatás rendszerének kibővitésére és fejlesztésére fordította a költségvetés. A gazdaságpolitika szándéka az volt, hogy „segély helyett munkát” adjon a korábban inaktívaknak is, és így lehetőséget teremtsen a munkaerőpiacra való visszatérésre. A program jellege a tekintetben átmeneti, hogy nem célja e formában a munkaerőt tartósan lekötni: a résztvevők létszáma 2016 óta fokozatosan csökken. Szándéka szerint lehetőséget teremt az elsődleges munkaerőpiaci részvételre (amelynek aránya fokozatosan emelkedik, hiszen a korábban 220 ezres létszámot is megközelítő állomány mára 160 ezer fő alá csökkent úgy, hogy ezzel párhuzamosan nőtt az aktivitási és csökkent a munkanélküliségi ráta), valamint hatékony eszköz a gazdaság ciklikus ingadozásainak munkapiaci tompítására, a hiszterézis mérséklésére. 
A reformok eredményeképp az aktivitás és a foglalkoztatás látványos bővülésnek indult, a munkanélküliségi ráta pedig 2018 elejére az Európai Unióban a legalacsonyabbak közé csökkent (3,9 százalék).

A mediterrán országok célirányos reformok helyett megszorító intézkedésekkel próbálták egyensúlyba hozni a költségvetéseket, ami azonban súlyos növekedési áldozatokkal járt. Portugáliában 2011-ben átlagosan 5 százalékkal csökkentették az állami szektorban foglalkoztatottak bérét, valamint döntöttek a nyugdíjak befagyasztásáról. 2013-tól bevezették a nyugdíjak progresszív rendszerben történő csökkentését, valamint az állami szektorban foglalkoztatottak bérének további csökkentését (szintén progresszív rendszerben). Mindemellett 2011 és 2014 között a közszektorban foglalkoztatottak száma 10 százalékkal csökkent. Spanyolországban 2011-ben szintén befagyasztották a nyugdíjakat. Eközben 2011 harmadik negyedéve és 2013 első negyedéve között 375 ezer fővel csökkent a közszférában foglalkoztatottak száma. Görögországban a közalkalmazotti bérek visszavágása mellett 2011-től az 1000 euro feletti nyugdíjakat is csökkentették, majd 2012-től a 13-14. havi nyugdíjakat teljesen eltörölték. 2013-ban 15 ezer közalkalmazottat bocsátottak el. 2014-ben további négy évre teljesen befagyasztották az állami béreket és a nyugdíjakat.

Összességében a mediterrán országok a fiskális válságkezelés hagyományos útját választották, míg Magyarország strukturális reformokat hajtott végre. Bár a válság első éveiben az EU többi országához hasonlóan a ClubMed-országok is lazítottak költségvetési politikájukon, a korábban felhalmozott egyensúlytalanságok következtében ez fenntarthatatlannak látszott, így 2010 után a gazdaságpolitikájuk átgondolására kényszerültek. A nemzetközi szervezetek ajánlásain alapulva a mediterrán térség országai jelentős, a belső reformokat nélkülöző költségvetési szigorításba kezdtek, ami - hasonlóan a 2008-2009-es magyar válságkezeléshez - a várakozásoknál is nagyobb mértékben fogta vissza a GDP-t, azaz mélyítette a recessziót.

A magyar költségvetési fordulat azért lehetett - és lett is - sikeres, mert élénkitette a növekedést és a foglalkoztatást, valamint szélesitette az adóalapot. A belső reform egyik sarokköve az adócentralizáció súlyának elmozdítása volt a munkát terhelő adók felől a fogyasztást terhelő adók irányába. A cél a munkaerőpiac keresleti és kínálati oldalának ösztönzése és a gazdaság fehérítése volt. A munkavállalás és családtámogatás mellett a kormány a kkv-szektor profitábilis múködését is támogatta a társasági adó többlépcsős csökkentésével, valamint az egyszerüsített, kedvezményes kisvállalati adózási formák kialakításával. A költségvetési egyensúly megteremtését a forgalmi adók növelése és a társadalmi szempontból nagyobb teherbírású szektorok (banki, energetikai, telekommunikációs és kiskereskedelmi szektorok) fokozott adóztatása (szektorális különadók) biztosította. A költségvetési egyensúlyt bevételi oldalról további gazdaságfehérítő intézkedések (pl. online pénztárgépek és az EKÁER bevezetése), kiadási oldalról pedig a strukturális reformok, közte a korkedvezményes és rokkantnyugdíjazási formák racionalizálása támogatta (Széll Kálmán-tervek). 


\section{A monetáris politika különbségei Magyarországon és az eurozónában}

Egészen eltérő monetáris politikai keretrendszerben nézett szembe a válsággal Magyarország és az eurozóna mediterrán régiója, ami nagyban meghatározta a fiskális és a monetáris politika közti összhang - a válságkezelés során kulcskérdéssé vált - lehetőségét. Mivel a fiskális politikában a költségvetési szabályok erős korlátot jelentenek az élénkítésre vonatkozóan, ezért az utóbbi években relatíve felértékelődött a monetáris politika szerepe. Míg az eurozóna tagországainak egységes monetáris politikáját az Európai Központi Bank határozza meg, addig Magyarországon a Magyar Nemzeti Bank önálló - szükség esetén hatékonyan célzott - monetáris politikát folytathat. A mediterrán gazdaságokban a rögzített árfolyamrendszer az önálló jegybanki célok és eszközök szabad megválasztásáról való lemondással járt, ami leszűkítette a gazdaságpolitikájuk lehetőségeit. Mivel fiskális politikájuk sem generált inflációt, így a kellő monetáris lazítás nélkül erős dezinflációs, majd deflációs környezet alakult ki ebben a térségben, ami a deflációs spirál kialakulásával is fenyegetett (12. ábra).

\section{2. ábra}

Magyarország és az eurozóna mediterrán tagországainak éves átlagos inflációja

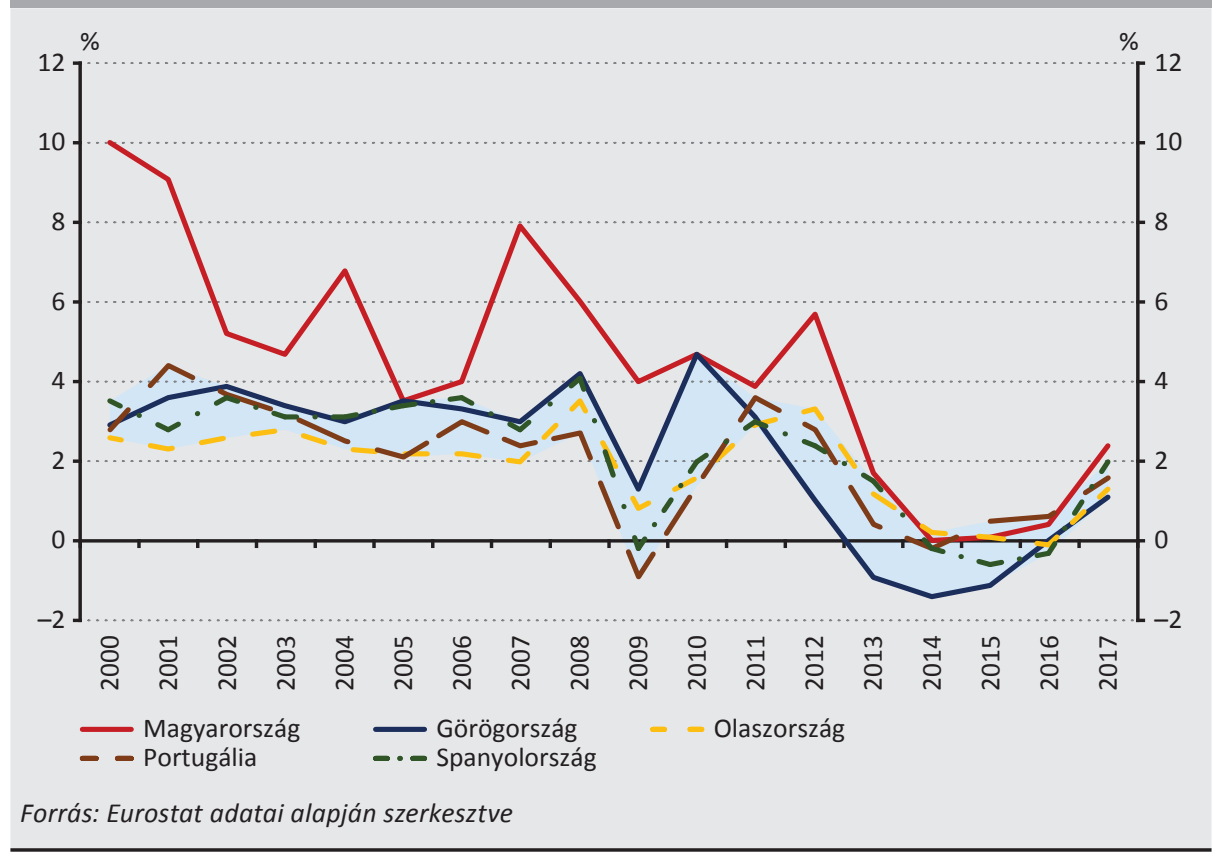


Az önálló monetáris politika lehetöséget teremtett Magyarországon arra, hogy konstruktiv összhang alakuljon ki a költségvetési és a jegybanki politika között. Erre ugyanakkor csak 2013-tól, az új jegybanki vezetés hivatalba lépésével kerülhetett sor. 2013-tól az MNB innovatív, a stabilitást és a gazdasági növekedést egyaránt ösztönző programokat vezetett be, így hazánk válságkezelése a mediterrán modellnél eredményesebb lehetett. Az MNB a kamatcsökkentési ciklusokon, a vállalati hitelezést és beruházást ösztönző Növekedési Hitelprogramon (NHP) és a Növekedéstámogató Programon, továbbá az ország makropénzügyi sérülékenységét csökkentő Önfinanszírozási Programon és - a kormánnyal együttmúködésben - a háztartások devizaalapú hiteleinek forintosításán keresztül a gazdaság egészét támogatta és támogatja.

\subsection{A monetáris politikai fordulat és célzott intézkedések Magyarországon}

A költségvetési stabilizáció és az önálló monetáris politika Magyarországon 2013-tól lehetővé tette a monetáris politikai fordulatot, ami az alapkamat jelentős csökkentésén és célzott intézkedéseken nyugodott.

Az alapkamat csökkentése a beruházások és a fogyasztás növelése mellett valamennyi gazdasági szektorban csökkentette a kamatterheket. Az alacsony infláció és a költségvetési konszolidációt követő javuló gazdasági megítélés megfelelő mozgásteret teremtett a Magyar Nemzeti Bank számára, hogy tartósan kedvező, a gazdaságot érdemben támogató monetáris kondíciókat teremtsen. Ennek első és hagyományos eszköze volt a jegybanki alapkamat prudens és fokozatos csökkentése, amelynek következtében az irányadó eszköz kamata 2012 (azaz, az MNB Monetáris Tanácsának akkori új külsős tagjainak támogatásával elindított kamatcsökkentésektől) és 2016 között 7 százalékról a mindenkori legalacsonyabb értékére, 0,9 százalékra csökkent (13. ábra). Az állampapírpiaci hozamok - az alacsony infláció, a kedvező nemzetközi pénzpiaci környezet és hazánk javuló kockázati megítélése mellett - követték az alapkamat alakulását, ami azt mutatta, hogy a befektetők is megalapozottnak és hitelesnek látják a monetáris politikát. A hozamok csökkenése jelentősen mérsékelte az állam kamatkiadásait. A megtakarítás mértéke 2013 óta összesen elérte a GDP 4,5 százalékát (1 600 milliárd forint). 


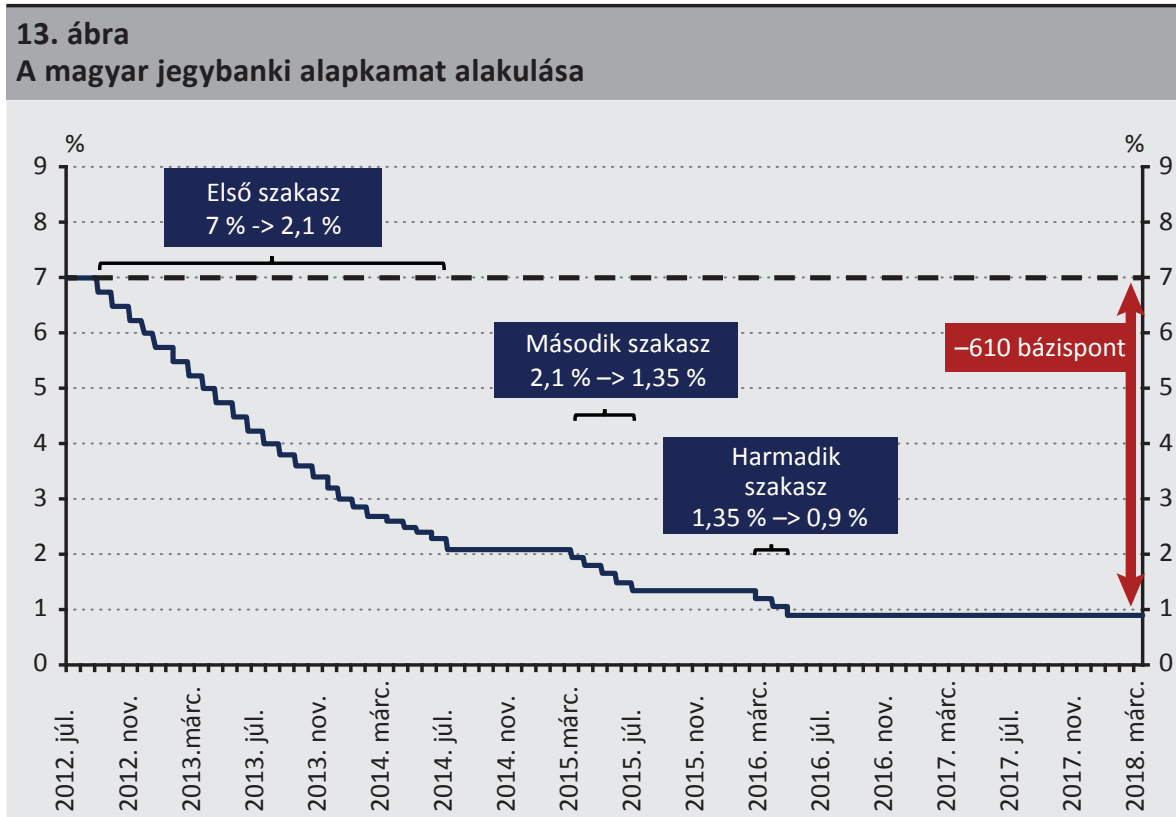

Forrás: Magyar Nemzeti Bank (2017) és az aktuális adatok alapján szerkesztve

A Növekedési Hitelprogram és később a Növekedéstámogató Program olyan célzott, a kkv-szektort támogató eszközök, amelyek révén sikerült elkerülni a hitelezés nélküli kilábalás veszélyét. Az általános, hagyományos eszközök mellett - hasonlóan néhány külföldi jegybankhoz - a Magyar Nemzeti Bank is alkalmazott célzott, nemkonvencionális eszközöket a korábban soha nem tapasztalt pénzpiaci és reálgazdasági válság hatékony kezelése céljából. Ilyen volt az MNB 2013 tavaszán bejelentett Növekedési Hitelprogramja, amely a kereskedelmi bankok elégtelen kisvállalati hitelezési aktivitását igyekezett oldani. Reális veszélye volt ugyanis annak, hogy a 2009 közepétől folyamatosan évi közel 6 százalékos zsugorodást mutató hitelpiac teljesen befagy, ami tartós, a potenciális növekedést is csökkentő növekedési áldozattal járt volna. A probléma kezelésére az MNB 0 százalékon kínált refinanszírozási hitelt a kereskedelmi banki szektornak, amelyet maximum 2,5 százalékos felárral helyezhettek ki a kkv-szektor részére (állóeszköz-beruházás, forgóeszköz-vásárlás, devizahitel-kiváltás és uniós támogatások előfinanszírozása céljából). A program keretein belül összesen közel 40 ezer kkv részesült kedvezményes hitelben mintegy 2800 milliárd forint (a GDP 8 százaléka) összegben. Az NHP, valamint a 2016-tól bevezetett Növekedéstámogató Program (NTP) - melynek célja az NHP fokozatos kivezetése és a vállalati hitelezés zökkenőmentes átállítása piaci alapokra - sikerének köszönhetően megállt a hitelzsugorodás, és 2016 végére a kkv-szektor hitelállománya már dinamikusan emelkedett (14. ábra). 
Az alapkamat-csökkentési ciklusok és a hitelezési aktivitást támogató jegybanki programok az elmúlt években, közvetlen és közvetett módón, a gazdasági növekedés mintegy feléhez járultak hozzá a Magyar Nemzeti Bank (2016) számításai szerint, amely intézkedések a potenciális növekedésre is pozitív hatást gyakoroltak.

\section{4. ábra \\ A teljes vállalati és a kis- és közepes vállalati szektor hitelállományának növekedési üteme Magyarországon}

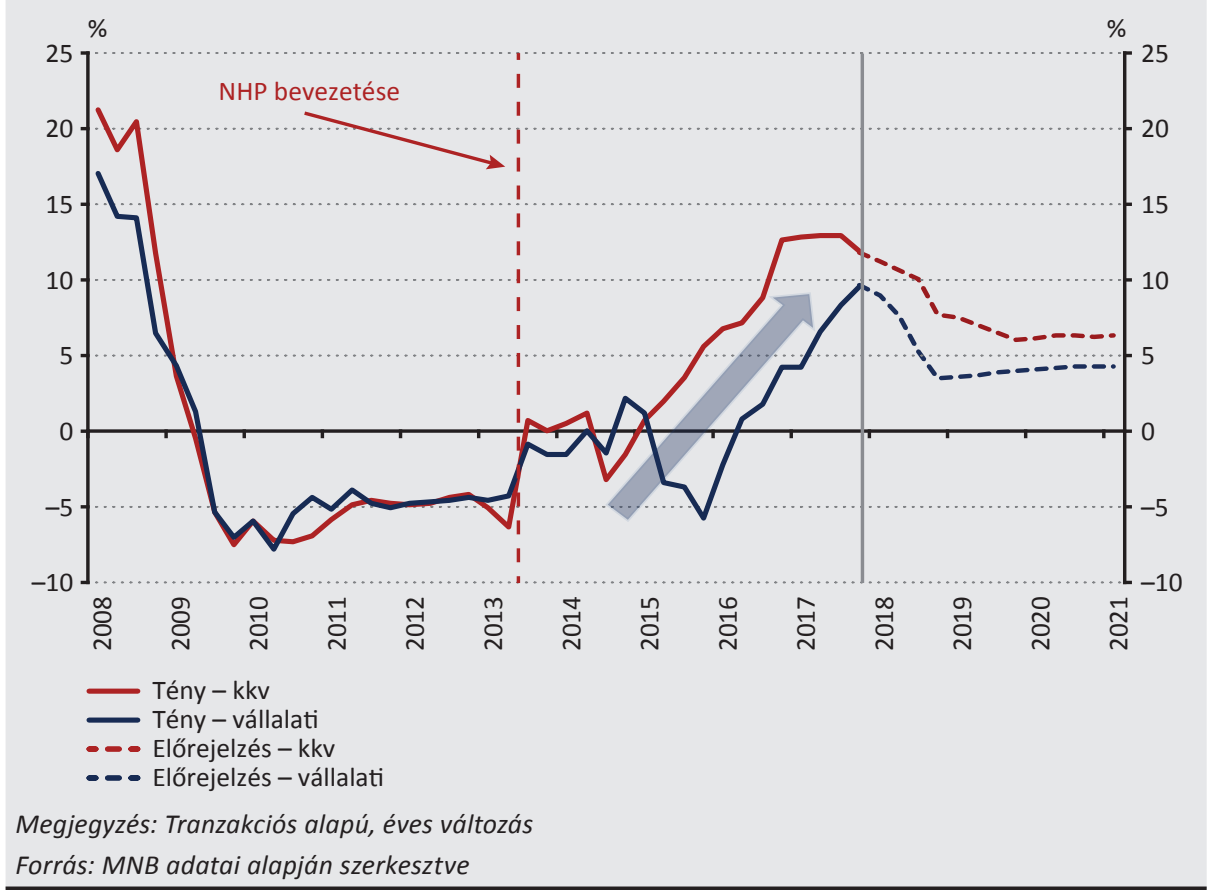

A Magyar Nemzeti Bank Önfinanszírozási programjának célja a gazdaság külsó sérülékenységének csökkentése. Az Önfinanszírozási programot a jegybank 2014 közepén vezette be, amelyet 2015-ben és 2016-ban több fázisban bővített. A program elsődleges célja a nemzetgazdaság külső sérülékenységének csökkentése, kockázati megítélésének javítása, valamint a jegybanki devizatartalékolási kötelezettség mérséklése volt a külföldi finanszírozás csökkentésén és ezzel párhuzamosan a belföldi befektetői bázis bővítésén keresztül. Ennek érdekében arra ösztönözte az MNB a kereskedelmi bankokat, hogy a likvid forrásaikat az MNB sterilizációs eszköze helyett más likvid eszközben, értékpapírban tartsák. A program keretében a jegybank irányadó eszköze kéthetes kötvényből három hónapos betétté alakult, így likviditása számottevően csökkent. Emellett átmenetileg bevezetésre került a jegybanki feltételes kamatcsereeszköz (interest rate swap, IRS) a kereskedelmi bankok hosszú távú, fix kamatozású értékpapírok vásárlásából eredő kamatkockázatának csökkentésére 
(Magyar Nemzeti Bank 2015). A program számottevően hozzájárult az államadósság finanszírozási szerkezetének javulásához, valamint az árfolyamkitettség mérséklődéséhez az adósság külföldi tulajdoni hányada és a devizarészarány szignifikáns csökkenésén keresztül. A 2011. végi kimagasló értékeket követően ma már mindkét mutató értéke történelmi mélyponton van (15. ábra).

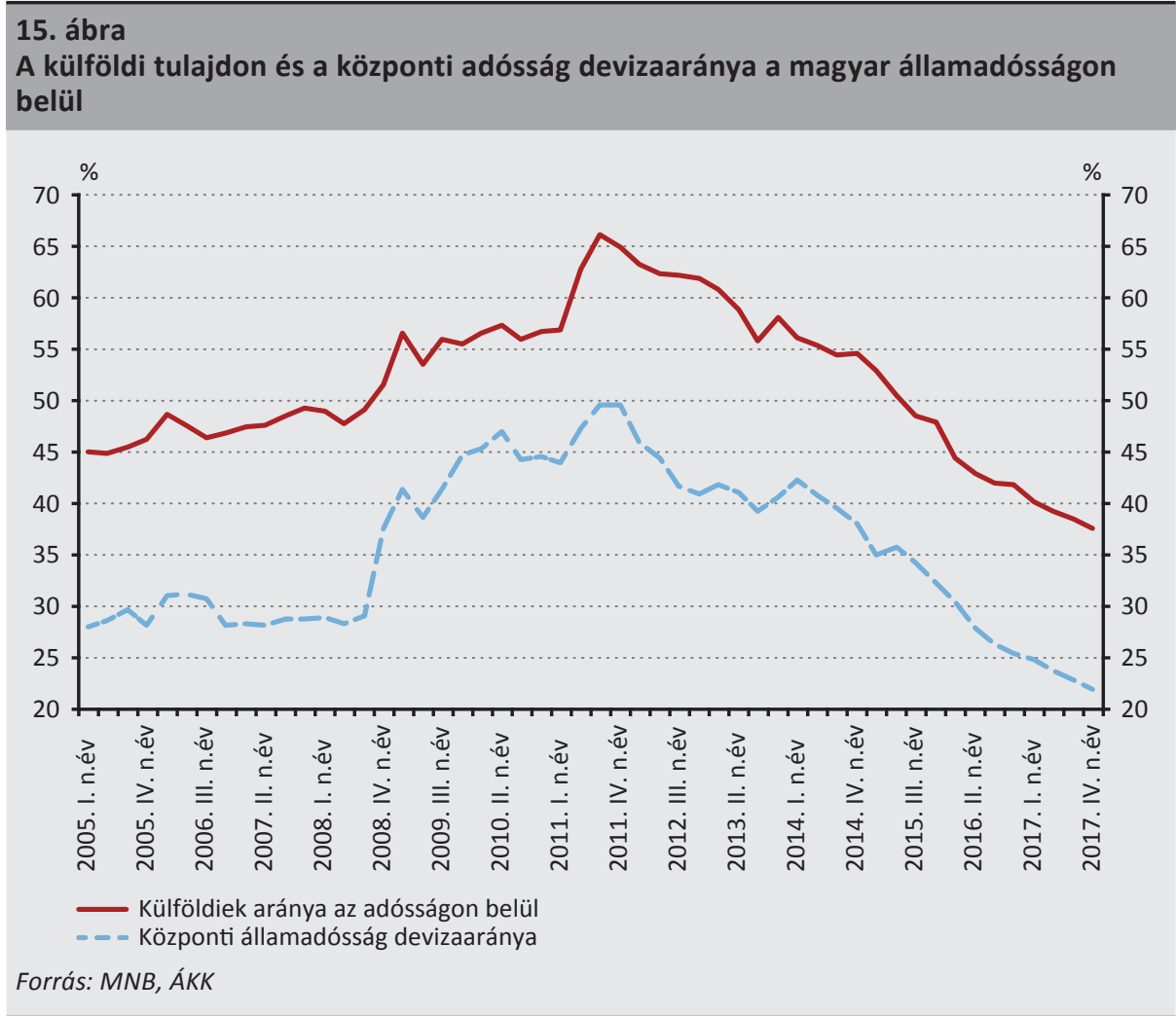

A háztartások deviza alapú jelzáloghiteleinek - kormányzattal és bankszektorral közös - kivezetése gazdasági és társadalmi katasztrófától mentette meg az országot. A deviza alapú hitelek 2003-tól kezdődő széleskörű és nagymértékű elterjedése következtében a 2008-as globális válság kirobbanására a magánszektor jelentős része már devizában volt eladósodva, ami a szignifikáns árfolyamkitettség miatt nemzetközi összevetésben is jelentős rendszerkockázatot eredményezett (16. ábra). A válság okán bekövetkezett jelentős forintgyengülés hatására ugyanis számottevően megemelkedtek a hiteladósok havi törlesztőrészletei, így százezrek lakhatása vált bizonytalanná. Ezzel párhuzamosan a törlesztőrészletek megnövekedése az aggregált keresletet is visszafogta, hiszen csökkentette az adósok rendelkezésre álló jövedelmét és fogyasztását, továbbá drasztikusan (4-6-szorosára) megemelte a nem teljesítő hitelek (non-performing loan, NPL) arányát a bankszektorban, ami 
a pénzügyi rendszer stabilitására jelentett kockázatot. Mindemellett a széles körben elterjedt devizahitelek gátolták a monetáris politika transzmissziós mechanizmusát is, mivel a külföldi valutában denominált hitelek kamatára a magyar monetáris politika nem volt hatással. A társadalom és a gazdaságpolitika elemi érdekévé vált a deviza alapú hitelkonstrukciók mielőbbi kivezetése, ami iránt határozott szándékot csak a 2010 utáni kormányzat mutatott.

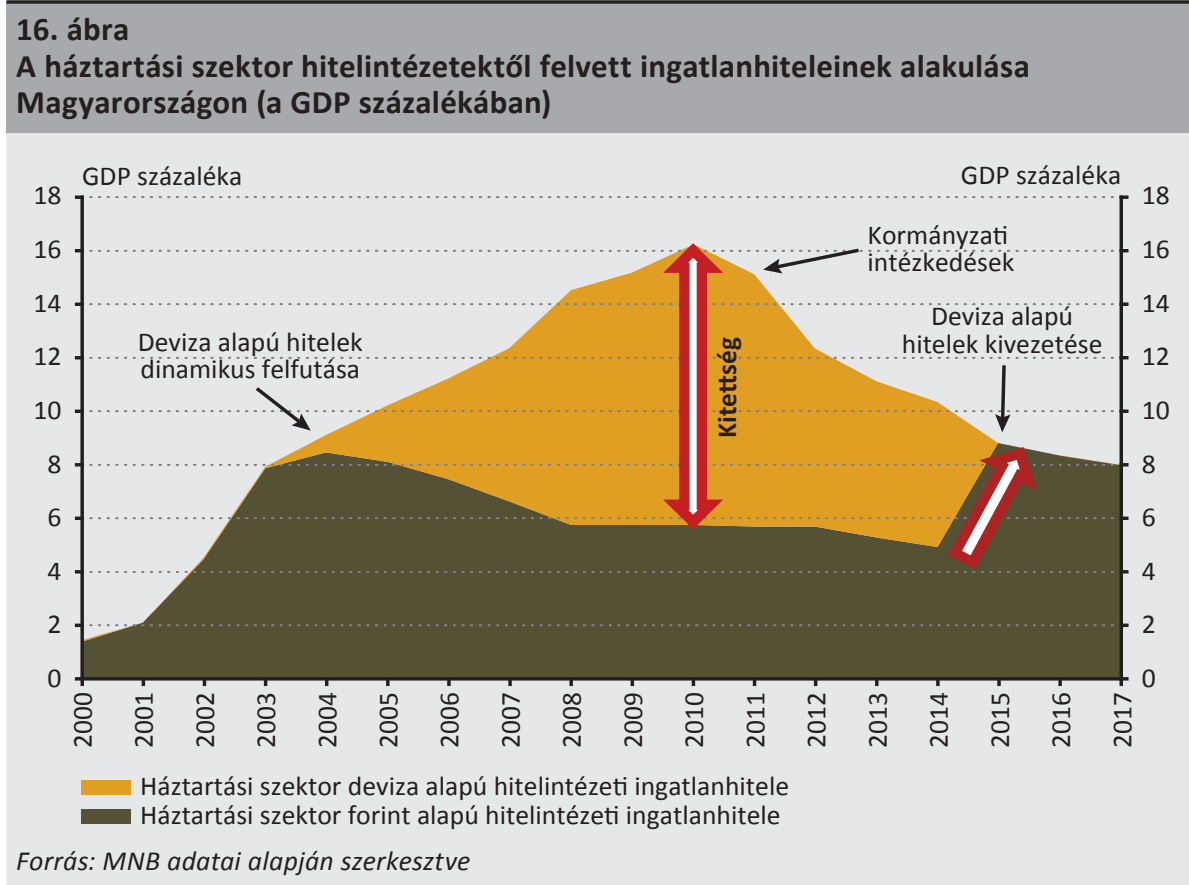

2013-tól a Magyar Nemzeti Bank minden rendelkezésére álló segítséget megadott a háztartási devizahitelek rendezéséhez. A Kúria 2014 közepi jogegységi határozata előtt az MNB proaktív szerepet vállalt a kormány és a Bankszövetség közt zajló tárgyalásokban, ezt követően pedig érdemben hozzájárult a lakossági devizahitelek sikeres forintosításához a bankszektor számára ehhez szükséges devizalikviditás ( 9 milliárd euro) biztosításával (Kolozsi et al. 2015). A forintosítás sikeres végrehajtása - a pénzpiaci spekulációk megelőzése - érdekében a konverziós árfolyamot előre és a pénz- és tőkepiaci szereplők előzetes tudta nélkül kellett rögzíteni, ami a három szereplő; a kormány, a jegybank és a Bankszövetség szoros együttmúködését igényelte (Nagy 2015). A devizahitelek konverziója 2014 őszén indult meg a lakossági jelzáloghitelek kivezetéséhez kapcsolódó devizatenderek kiírásával, amelyet 2015ben a személyi, majd a gépjármű hitelek követtek, így 2015 végére a magyar háztartások mérlegében gyakorlatilag nem maradt devizahitel. A korábban svájci frank alapú lakáshitelek átlagos havi törlesztőrészlete mintegy 25 százalékkal csökkent. Az intézkedéssorozat jelentőségét utólag nagyban felértékelte, hogy mindezt még 
azelőtt sikerült végrehajtani, mielőtt a svájci jegybank megszüntette az árfolyamküszöbét az euróval szemben, a svájci frank így bekövetkezett további erősödése ugyanis beláthatatlan következményekkel járt volna.

\subsection{Az Európai Központi Bank válságkezelése nem volt elégséges a ClubMed-or- szágok számára}

Az eurozóna közös monetáris politikája gyakorlatilag nem hagy lehetöséget a nemzetgazdasági szintü, célzott jegybanki eszközök alkalmazására. Ez akkor lenne megfelelő gyakorlat, ha az eurozóna optimális valutaövezet lenne, de a válság rávilágított arra, hogy ez nincs így. Az eurozónába való belépés feltételei, az ún. maastrichti kritériumok teljes egészében a nemzetgazdaságok pénzügyi stabilitására, illetve annak is csak néhány szegmensére koncentrálnak (infláció, hozamok, árfolyamstabilitás, államháztartás). A valutaövezet valóban sikeres múködésének azonban megítélésünk szerint további feltételei is vannak. Ezeket Nagy és Virág (2017) a következőkben foglalta össze: (i) reálkonvergencia, (ii) üzleti ciklusok harmonizáltsága, (iii) hasonló fokú versenyképesség, (iv) megfelelő pénzügyi szektor, (v) elérhető anticiklikus politikák. Ezen mutatók mentén azonban jelentős különbségek jellemzik az euroövezetet. A perifériaországok jellemzően jelentősebb deflációs kockázatokkal és magasabb munkanélküliségi rátákkal szembesültek. Az északi és a déli országok gazdasági helyzete és struktúrája eltérő volt már az egységes valutaövezethez való csatlakozásuk idején is, az eltéréseket a válság felerősítette. Az eurozóna nem teszi lehetővé a nominális árfolyamon keresztüli alkalmazkodást, ugyanakkor nem zárta ki, hogy az euroövezeti tagországok között jelentős reálárfolyam-különbségek alakuljanak ki. A reálárfolyam-különbségek kialakulásának egyik fontos mozgatórugója volt az eltérő bérdinamika (Sapir 2016).

Az Európai Központi Bank a nemkonvencionális eszközöket megkésve alkalmazta, ami mélyítette a válság hatásait több tagországban. Az EKB a válság kitörésekor gyors kamatcsökkentésekkel reagált, ám a többi monetáris politikai eszközt megkésve alkalmazta (Matolcsy 2015), ami miatt relatíve szigorúak maradtak a monetáris kondíciói ${ }^{8}$. A szuverén adósságválság kezelése során a periféria-országokat fenyegető csőd elkerülése érdekében az EKB intézkedéseinek célja a kötvénypiaci felárak mérséklése és a transzmisszió helyreállítása volt. Az EKB 2010-ben kezdte meg az Értékpapírpiaci programot (Securities Market Programme, SMP), ami a mediterrán országok államkötvényeinek vásárlásán keresztül igyekezett a túlzott felárakat leszorítani. A program méretéből adódóan a felárak emelkedését volt csak képes megállítani, a tartós hozamcsökkenést nem tudta elérni. A magas hozamok fennmaradása a perifériaországokban hozzájárult az államadósság-ráták fenntarthatatlan szintjéhez és ahhoz, hogy külső finanszírozási segítségre szorultak. A teljes program során vásárolt kötvényállomány 217 milliárd euro volt, ami az érintett olasz,

\footnotetext{
${ }^{8}$ Ezt súlyosbította, hogy túlságosan hamar próbált kamatemelési ciklust indítani, már 2011-ben.
} 
spanyol, portugál, görög és ír papírok tekintetében hosszú távon nem bizonyult elégségesnek (Lehmann - Mátrai - Pulai 2013). A program nem volt transzparens, az EKB nem kommunikálta a vásárlásait és azok egyedi értékét, csak a teljes állományt, így nem került ki információ arról, hogy országonként mekkora összegben vásárolt. A piaci reakciókban jól mutatja a különbséget, amikor Mario Draghi elnök „Whatever it takes” beszéde és a monetáris célú végleges értékpapír-adásvételi ügyletek (Outright Monetary Transactions, OMT) bejelentése után a mediterrán országok hozamai gyorsan közeledni kezdtek a magországok hozamaihoz. A két eszköz között a különbség a mennyiségben volt, mert az OMT egyik fö üzenete, hogy nincs felső korlát a tervezett vásárlásokban. Az EKB kommunikációjában többször említette, hogy strukturális reformokra és a fiskális politika átalakítására volt szükség ezekben az országokban. Mégis kérdéses, hogy egy OMT-jellegű intézkedéssel célszerű volt-e várni 2012-ig. Demertzis és Wolff (2016) szerint az első eszközvásárlások mérete a GDP-hez mérve rosszul lett kiszámítva, és ezt csak 2016-ra korrigálta az EKB. ${ }^{9}$

Összességében az adósságválság elmélyülése és a visszafogott monetáris politika a fö célt, az inflációs cél elérését sem tette lehetövé az eurozónában (Demertzis - Wolff 2016). A fokozatosan bevezetett és bővített nemkonvencionális eszközök hozzájárultak a gazdaság élénkítéséhez, ugyanakkor hatásuk nem bizonyult elegendőnek.

\section{A magyar reformok eredményessége a mediterrán országok tükrében}

Az eltérő válságkezelési eszközök eltérő eredményekre vezettek a mediterrán régióban és Magyarországon ${ }^{10}$. A hagyományos válságkezelési logikával ellentétben Magyarországnak előbb sikerült a költségvetését is stabilizálnia és a gazdasági növekedését is újraindítania, mint a mediterrán országoknak. Megítélésünk szerint ez elsősorban a foglalkoztatáspolitikai fordulat sikerén múlott, amelyhez a vállalati beruházásokat támogató gazdaságpolitika is jelentős mértékben hozzájárult. A magyar lépésekkel ellentétben a dél-európai kiigazítások súlyosan érintették a foglalkoztatás mellett a tőkefelhalmozást is, ami az aggregált keresleten túl a hosszú távú növekedési képességet is negatívan befolyásolta. 2007 és 2013 között Magyarország GDP-arányos beruházási rátája kevesebb mint 3 százalékponttal (24-ről 21 százalékra) mérséklődött, míg a ClubMed-országoké átlagosan több mint 9 százalékponttal (25-ről 16 százalékra) csökkent. Ezt követően 2017-ig stagnálás, enyhe növekedés jellemezte a mutató alakulását mindegyik országban. A 2010-es szintet egyedül

\footnotetext{
${ }^{9}$ Az Európai Központi Bank válságkezelésének átfogó elemzése meghaladná a tanulmány kereteit, erről további információ található a Magyar Nemzeti Bank (2017) kiadvány 4. fejezetében.

${ }^{10}$ A fejezet ábráinak kidolgozásához alapot nyújtott Matolcsy György, a Magyar Közgazdasági Társaság 2017. évi Közgazdász-vándorgyűlés nyitó plenáris ülésén tartott előadása (Matolcsy 2017).
} 
Magyarországnak sikerült meghaladnia 2017-re (21,5 százalék), míg a mediterrán országok továbbra is alatta maradnak, átlagosan 16,7 százalékkal.

A magyar gazdaságpolitika szándékaival összhangban 2018-ra a gazdaság lényegében elérte a teljes foglalkoztatást. A foglalkoztatottak száma 2010 és 2017 között közel 20 százalékkal nőtt (3,7 millióról 4,4 millióra), a foglalkoztatási ráta 55 százalékról 68 százalékra emelkedett. Magyarország foglalkoztatási rátája a második legnagyobb mértékben javult az Unióban, amellyel nemcsak az EU, hanem a visegrádi országok átlagos szintjét is sikerült mára utolérni, a mediterrán zónatagokét pedig meghaladni. A mediterrán országok esetében komoly strukturális problémákat sejtet, hogy a foglalkoztatási ráta terén mindeddig nem közelítették meg a válság előtti pozícióikat (17. ábra). Még inkább beszédes, hogy Magyarországon a munkanélküliségi ráta 2018 elején történelmi mélypontra, 3,9 százalékra csökkent. Ezzel szemben a mediterrán országokban a válság előtt jellemző 6-9 százalékos szintet még egyik országnak sem sikerült elérnie (18. ábra).

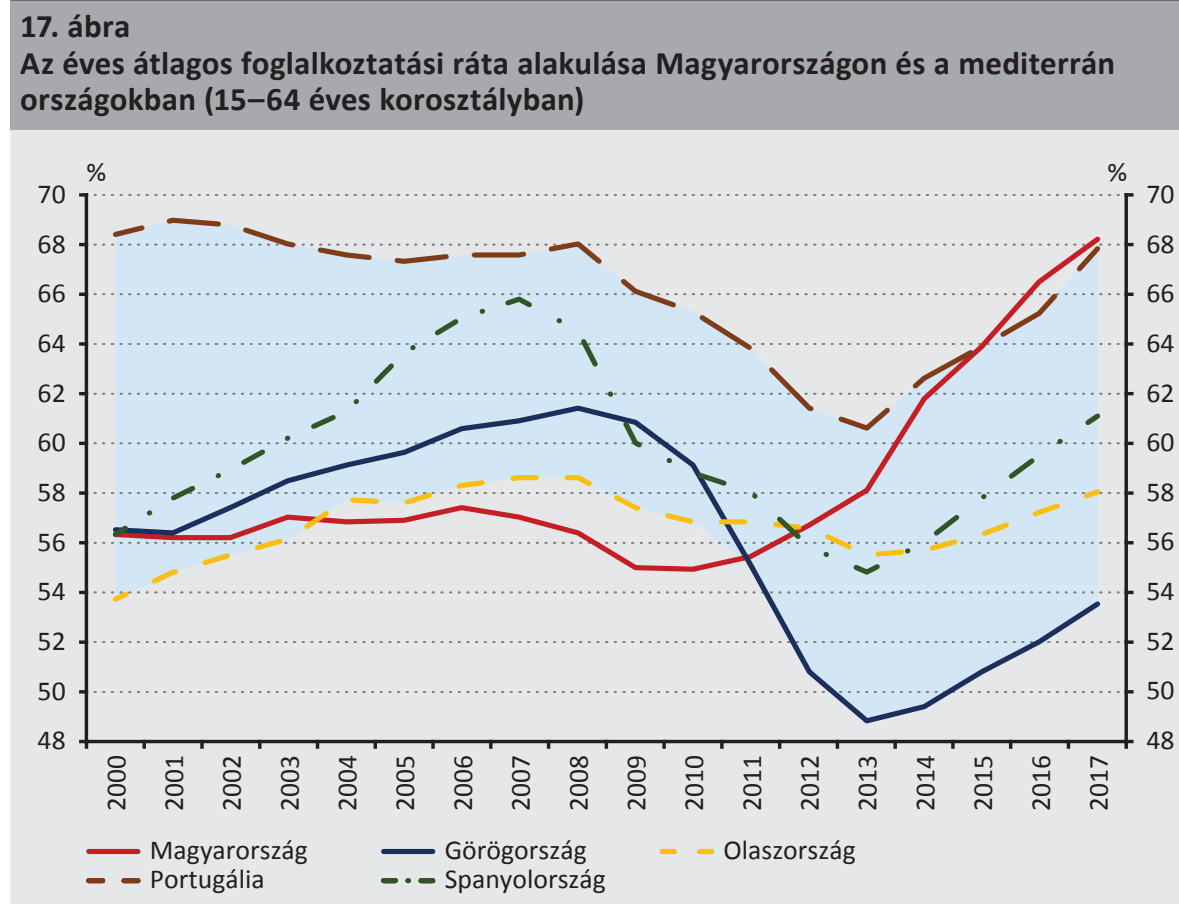

Forrás: Eurostat adatai alapján szerkesztve 


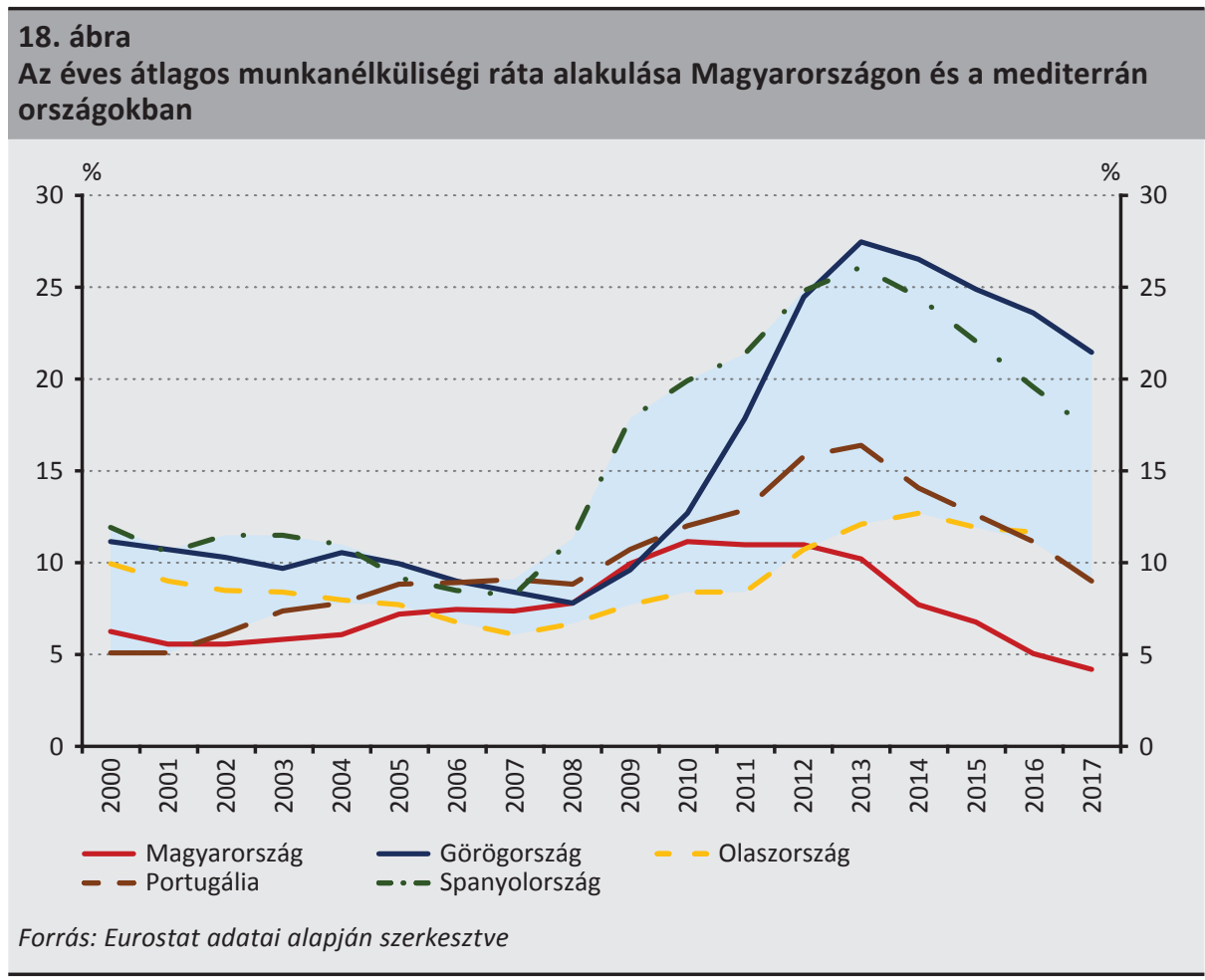

A foglalkoztatás bővülése megteremtette az alapját a magyar gazdaság növekedésének, míg a mediterrán országok még 2016-ban sem érték el a válság előtti GDP szintjét (19. ábra). A hazai GDP a 2009-es recessziót követően 2017-ig összesen közel 17 százalékkal bővült, mintegy 11 százalékkal meghaladva a válság előtti, 2007-es szintet. 2013 óta a magyar gazdaság növekedési üteme szignifikánsan meghaladja az uniós átlagot, és - a válság előtti időszakkal ellentétben - megegyezik a visegrádi régió átlagos bővülési ütemével. Ezzel szemben a mediterrán térség nehézkes kilábalását mutatja, hogy a ClubMed-országok - Spanyolország kivételével - mindmáig nem tudták még elérni a 2007-es szintjüket. Görögország több mint 25 százalékos növekedési veszteséget szenvedett el, amelyet 2013 óta sem tud ledolgozni. 


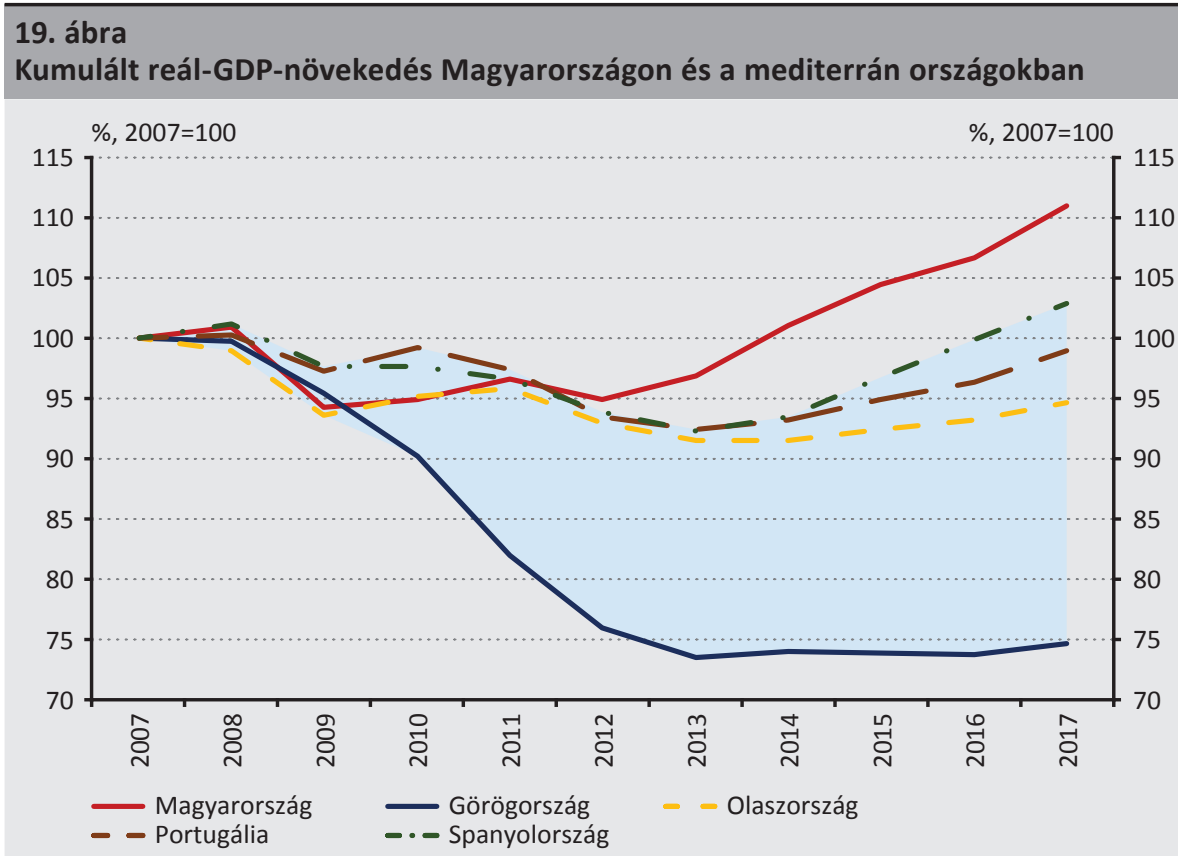

Forrás: Eurostat adatai alapján szerkesztve

Magyarország 2010 után az adóreform révén úgy tudott mozgásteret teremteni a reformintézkedések megvalósításához, hogy egyidejüleg és tartósan biztosította a költségvetés egyensúlyát. 2011-et követően a GDP-arányos magyar államháztartási hiány tartósan megfelel az Európai Unió 3 százalékos maastrichti deficit-kritériumának. Ezzel szemben a mediterrán országok többsége csak 2016-ra tudta teljesíteni az EU hiánykritériumát (1. ábra). A 2010-2013 közötti adóreform gazdaságélénkítő és ezen keresztül a költségvetési bevételeket gyarapító hatását fokozatosan fejtette ki, így az adóbevételek Magyarországon 2014 és 2016 között az adókulcsok növelése nélkül emelkedtek a GDP közel 2 százalékával (Palotai 2017).

Hazánkban a növekedésbarát költségvetési konszolidáció révén 2011-töl sikerült csökkenő pályára állítani az államadósság-ráta addig növekvő trendjét (Matolcsy - Palotai 2016). A GDP-arányos bruttó államadósság szintje a 2011-es 80,5 százalékos történelmi csúcsról 2017 végére 73,6 százalékra csökkent. 2010 és 2017 között Magyarország az ötödik legnagyobb mértékű adósságcsökkenést mutatta az EU-ban (összesen 10 országban csökkent, míg a többiben nőtt az adósságráta). Ezzel szemben a mediterrán zónatagok államadóssága a 2008-as válságot követő magas szinten stagnál (20. ábra). 


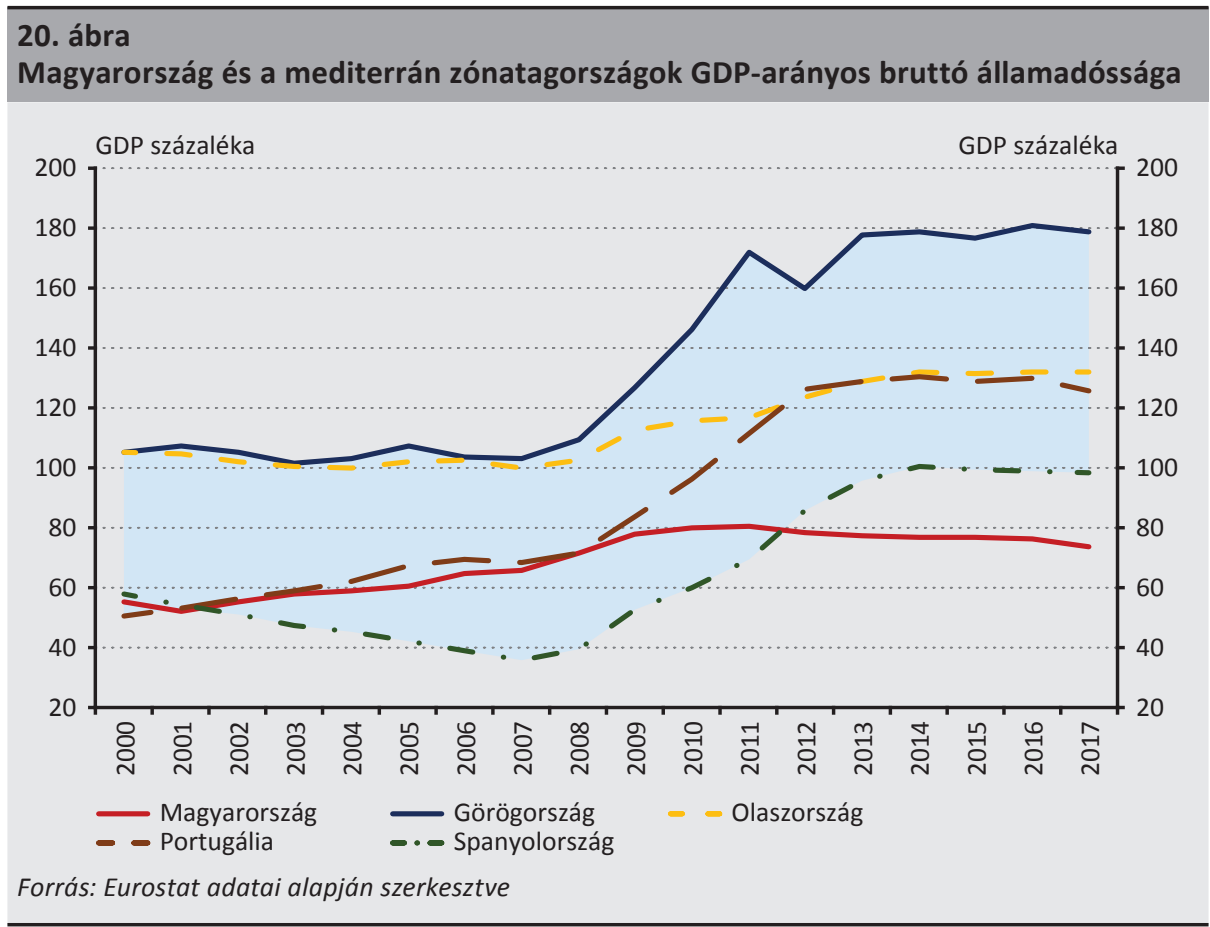

\section{6. Összegzés}

A magyar gazdaságpolitika 2010 utáni modellváltása az innovativ és célzott eszközök alkalmazásával nemzetközi viszonylatban is eredményes válságkezelést eredményezett. A globális pénzügyi válság kitörése óta eltelt 10 év már lehetővé teszi, hogy megvonjuk a válságkezelés mérlegét Magyarországon, és ezt összehasonlítsuk más országok eredményeivel.

A hasonló kiinduló helyzet ellenére a mediterrán országok és Magyarország szinte minden tekintetben a válságkezelés eltérő módját alkalmazták (21. ábra). A vizsgált ClubMed-gazdaságok az eurozóna részei, önálló monetáris politikát tehát nem folytathattak. A költségvetési kihívások kezelésére pedig a kiadások csökkentésének és az adók emelésének hagyományos útját választották (a korábbi fenntarthatatlan költségvetési lazítás korrekciójaként). Ezzel szemben Magyarország adóemelések helyett adóreformot hajtott végre, a költségvetési megtakarításokat pedig a foglalkoztatás ösztönzésének céljára fordította. A 2010 utáni költségvetési reformokat a Magyar Nemzeti Bank által 2013-tól végrehajtott monetáris politikai fordulat is támogatta, megteremtve ezzel a két fő gazdaságpolitikai ág nélkülözhetetlen és szoros összhangját (Lentner 2017). Az inflációs cél elérése érdekében indított kamatcsökkentések mellett innovatív, célzott lépések támogatták a kisvállalati hitelezést, 
a pénzügyi stabilitást és a külső eladósodás csökkentését. E strukturális változások megalapozták a fenntartható gazdasági növekedést. A sikeres felzárkózás biztosításához azonban a nemzetgazdaság versenyképességének további, a mennyiségi után már főleg a minőségi kritériumok további javítására szükséges fókuszálni.

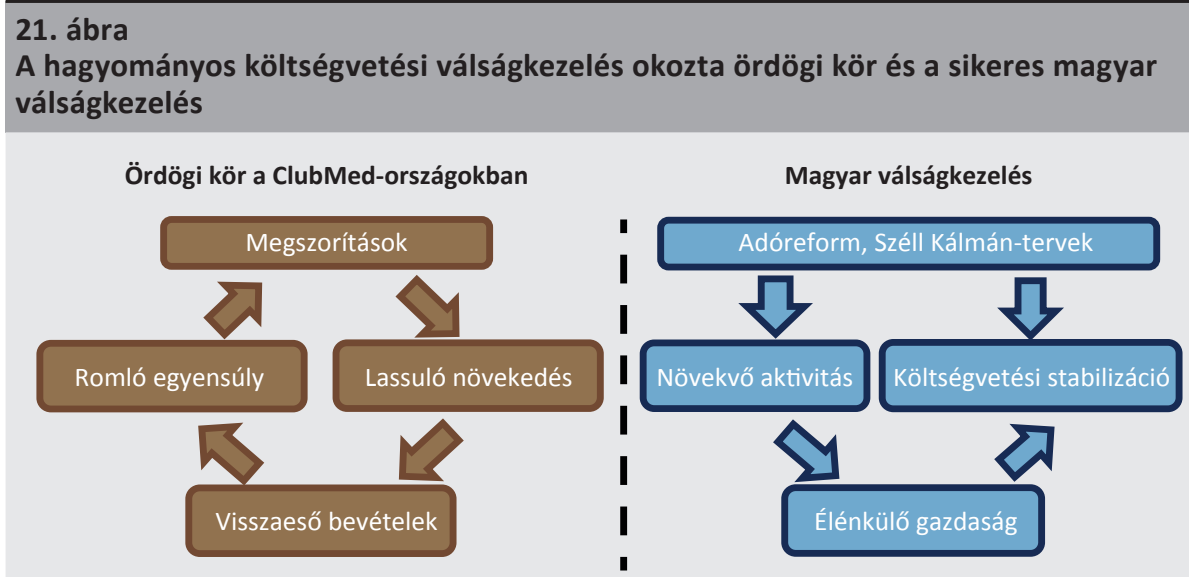

Forrás: $M N B$

A Magyarországon eredményesen végrehajtott, célzott strukturális reformokon alapuló stabilizációval szemben a mediterrán zónatag országok válságkezelése nem bizonyult sikeresnek. Ennek oka elsősorban a költségvetési megszorításokra, illetve a strukturális reformok, valamint az önálló, célzott és hatékony monetáris politika hiányára vezethetők vissza. A megkésett és nem hatékony monetáris, illetve a megszorításokra épülő hagyományos költségvetési válságkezelés jelentős reálgazdasági áldozatokkal járt, ami egy gazdasági ördögi kör kialakulását eredményezte. Ebből adódóan a mediterrán országok továbbra is a válság előttinél kedvezőtlenebb növekedési és munkaerőpiaci kondíciókkal, valamint magas szinten stagnáló államadóssággal küzdenek. Megítélésünk szerint amennyiben a ClubMed-országok a 2010 utáni magyar úthoz hasonló irányt és reformlépéseket követtek volna a válságkezelés időszakában, akkor kisebb növekedési áldozattal és előbb érhették volna el a költségvetési stabilitást és a munkaerőpiaci konszolidációt.

\section{Felhasznált irodalom}

Auerbach, A. J. - Gorodnichenko, Y. (2012): Measuring the Output Responses to Fiscal Policy. American Economic Journal: Economic Policy, 4(2): 1-27. https://doi.org/10.1257/pol.4.2.1

Banai Péter Benő - Palotai Dániel (2018): Fenntartható költségvetés - fenntartható nyugdijrendszer. Világgazdaság, február 8. 
Blanchard, O. - Leigh, D. (2013): Growth Forecast Errors and Fiscal Multipliers. IMF working paper.

Lentner, Cs. (2017): Scientific Taxonomy of Hungarian Public Finances After 2010. Civic Review, 13(Special Issue): 21-38. https://doi.org/10.24307/psz.2017.0303

Demertzis, M. - Wolff, G. B. (2016): The effectiveness of the European Central Bank asset purchase programme. Bruegel Institute, May.

Európai Bizottság (2011): Tax reforms in EU Member States. http://ec.europa.eu/economy_ finance/publications/european_economy/2011/pdf/ee-2011-5_en.pdf

Európai Bizottság (2013): Study on the impacts of fiscal devaluation. Taxation papers, Working paper Nr. 36.

Európai Bizottság (2017): Study and Reports on the VAT Gap in the EU-28 Member States. 2017 Final Report. https://ec.europa.eu/taxation_customs/sites/taxation/files/study_and_ reports_on_the_vat_gap_2017.pdf

Eyraud, L. - Weber, A. (2013): The Challenge of Debt Reduction during Fiscal Consolidation. IMF Working Paper, 13/67. https://doi.org/10.5089/9781475553864.001

House, C. - Proebsting, C. - Tesar, L. (2017): Austerity in the Aftermath of the Great Recession. NBER Working Papers Series No. 23147. https://doi.org/10.3386/w23147

Ilzetzki, E. - Mendoza, E. G.- Végh, C. A. (2013): How Big (Small?) are Fiscal Multipliers? Journal of Monetary Economics, 60(2): 239-254. https://doi.org/10.1016/j.jmoneco.2012.10.011

Kolozsi Pál Péter - Banai Ádám - Vonnák Balázs (2015): A lakossági deviza-jelzáloghitelek kivezetése: időzités és keretrendszer. Hitelintézeti Szemle, 14(3): 60-87. https://www.mnb.hu/ letoltes/3-kolozsi-banai-vonnak-1.pdf

Kolozsi Pál Péter - Lentner Csaba - Parragh Bianka (2017): Közpénzügyi megújulás és állami modellváltás Magyarországon. Polgári Szemle, 13(4-6): 28-51. https://polgariszemle.hu/ aktualis-szam/146-allampenzugyi-muhely-nemzetgazdasagtan/917-kozpenzugyi-megujulases-allami-modellvaltas-magyarorszagon

Lehmann Kristóf - Mátrai Róbert - Pulai György (2013): A Federal Reserve System és az Európai Központi Bank válság során alkalmazott intézkedéseinek bemutatása. MNB Szemle Különszám, 2013(október): 100-109.

Magyar Nemzeti Bank (2015): A Magyar Nemzeti Bank önfinanszírozási programja, 2014. április-2015. március. Magyar Nemzeti Bank. http://www.mnb.hu/letoltes/magyarnemzeti-bank-onfinanszirozasi-programja.pdf 
Magyar Nemzeti Bank (2016): Félidős jelentés 2013-2016. http://www.mnb.hu/letoltes/ felidos-jelentes-2013-2016-hun-0303.pdf

Magyar Nemzeti Bank (2017): A magyar út - Célzott jegybanki politika. Magyar Nemzeti Bank könyvsorozat, Magyar Nemzeti Bank.

Matolcsy György (2008): Éllovasból sereghajtó - Elveszett évek krónikája. Éghajlat Könyvkiadó Kft., Budapest.

Matolcsy György (2015): Egyensúly és növekedés. Magyar Nemzeti Bank könyvsorozat, Kairosz Könyvkiadó Kft.

Matolcsy György (2017): Tíz évvel a válság után 2007-2017. Előadás a Magyar Közgazdasági Társaság 2017. évi Közgazdász-vándorgyúlés nyitó plenáris ülésén, szeptember 7 . http://www.mkt.hu/wp-content/uploads/2017/09/nyito_Matolcsy_Gyorgy.pdf

Matolcsy György - Palotai Dániel (2016): A fiskális és a monetáris politika kölcsönhatása Magyarországon az elmúlt másfél évtizedben, Hitelintézeti Szemle, 15(2): 5-32. http://www.hitelintezetiszemle.hu/letoltes/matolcsy-gyorgy-palotai-daniel.pdf

Mosberger Pálma (2017): Egykulcsos társasági adó hatása. Szakmai cikk, MNB. https://www.mnb.hu/letoltes/mosberger-palma-egykulcsos-tarsasagi-ado-hatasa.pdf

Nagy Márton (2015): Forintositás - hogy is volt ez? Szakmai cikk, MNB. https://www.mnb.hu/letoltes/15-01-28-nagy-marton-istvan-forintositas-hogy-is-volt-ez.pdf

Nagy Márton - Virág Barnabás (2017): Felzárkózás az eurozónában - csakis megfeleló felkészültséggel teljesíthető. Szakmai cikk, MNB. https://www.mnb.hu/letoltes/nagymarton-virag-barnabas-felzarkozasi-az-eurozonaban-frissitett.pdf

OECD (2010): Tax Policy reform and Economic Growth. OECD Tax Policy Studies 20. OECD Publishing, Paris.

OECD (2017): OECD Tax database. http://www.oecd.org/tax/tax-policy/tax-database. htm\#VATTables

Palotai Dániel (2017): Beértek a 2010-2013 közötti adóreform kedvezö hatásai. Szakmai cikk, MNB. https://www.mnb.hu/letoltes/palotai-daniel-adoreform-gyumolcsei-mnbhonlapra.pdf

Prammer, D. (2011): Quality of taxation and the crisis: tax shifts from a growth perspective. Taxation papers NO. 29, Európai Bizottság.

Sapir, A. (2016): The eurozone needs less heterogenity. Vox article, 2016. 01. 12. https://voxeu.org/article/eurozone-needs-less-heterogeneity 
Sávai Marianna - Kiss Gábor Dávid (2017): Az államadósság mértékét meghatározó mutatók vizsgálata. A V4 és GIPS országcsoportok összehasonlító elemzése egylépéses dinamikus panelregresszió segítségével. Pénzügyi Szemle, 2017(4): 445-461. https://www.penzugyiszemle.hu/documents/savaim-kissgd-2017-4-mpdf_ 20180110163634_5.pdf

Szalai Ákos - Kolozsi Pál Péter (2016): Mit kell tennünk egy versenyképesebb magyar gazdaságért? - Gondolatok a Magyar Nemzeti Bank Versenyképesség és növekedés címü monográfiájával kapcsolatban. Polgári Szemle, 12(4-6).

Szoboszlai Mihály - Bögöthy Zoltán - Mosberger Pálma - Berta Dávid (2018): A 2010-2017 közötti adó- és transzferváltozások elemzése mikroszimulációs modellel. MNB-Tanulmányok - 135., február. https://www.mnb.hu/letoltes/mnb-tanulma-ny-135-vegleges.pdf

Trabandt, M. - Uhlig, H. (2012): How do Laffer curves differ across countries? WP No. 17862, National Bureau of Economic Research, February. http://www.nber.org/papers/w17862.pdf 